\title{
Application of Iron Oxide Nanomaterials for the Removal of Heavy Metals
}

\author{
Pragnesh N. Dave ${ }^{1}$ and Lakhan V. Chopda ${ }^{2}$ \\ ${ }^{1}$ Department of Chemistry, Krantiguru Shyamji Krishna Verma Kachchh University, Mundra Road, Bhuj, Gujarat 370 001, India \\ ${ }^{2}$ Chemical Engineering Department, Government Engineering College, Bhuj, Gujarat 370 001, India \\ Correspondence should be addressed to Pragnesh N. Dave; pragnesh7@yahoo.com
}

Received 15 July 2013; Revised 24 December 2013; Accepted 1 January 2014; Published 19 February 2014

Academic Editor: Bobby G. Sumpter

Copyright (c) 2014 P. N. Dave and L. V. Chopda. This is an open access article distributed under the Creative Commons Attribution License, which permits unrestricted use, distribution, and reproduction in any medium, provided the original work is properly cited.

In the 21st century water polluted by heavy metal is one of the environment problems. Various methods for removal of the heavy metal ions from the water have extensively been studied. Application of iron oxide nanaparticles based nanomaterials for removal of heavy metals is well-known adsorbents for remediation of water. Due to its important physiochemical property, inexpensive method and easy regeneration in the presence of external magnetic field make them more attractive toward water purification. Surface modification strategy of iron oxide nanoparticles is also used for the remediation of water increases the efficiency of iron oxide for the removal of the heavy metal ions from the aqueous system.

\section{Introduction}

Water is the most essential compound on the earth for the human activities. Proving clean water is the prime requirement of the human being for their better health. Water pollution is increasing worldwide due to rapid growth of industry, increase human population, and domestic and agricultural activities which leads to the life time threatening diseases [1]. Heavy metals pollution is becoming one of the most serious environment problems globally [2-5]. It is the most threat problem for population in dense countries particularly for China and India [6-10]. Its presence in low concentration of heavy metals in various water resources could be harmful to human health. The treatment of heavy metals is so important due to their persistence in the environment. In order to detoxify heavy metals, various techniques like photocatalytical oxidation, chemical coagulants, electrochemical, bioremediation, ion-exchange resins, reverse osmosis, and adsorption have been employed $[11,12]$. Among these nano-based adsorbents are the more convenient technologies for removal of heavy metals from the aqueous system [13-16]. Application of iron oxide based nanomaterial is more attractive for removal of heavy metals contamination from the water because of their important features like small size, high surface area, and magnetic property [17-22]. Magnetic property of iron oxide nanaparticles enables easy separation of adsorbents from the system and could be reused for further application. Reusability of iron oxide based nanomaterial leads to a decrease in the economic burden. Here in, we will provide detail account on iron oxides nanaparticles such as magnetite $\left(\mathrm{Fe}_{3} \mathrm{O}_{4}\right)$, maghemite $\left(\gamma-\mathrm{Fe}_{2} \mathrm{O}_{3}\right)$, and hematite $\left(\alpha-\mathrm{Fe}_{2} \mathrm{O}_{3}\right)$ based nanoadsorbents for removal of heavy metals from water/wastewater. We will put more emphasis on magnetite based nanoadsorbents.

\section{Iron Oxide Nanoparticles}

The synthesis of the above iron oxide nanoparticles is intensively developed not only for their fundamental scientific interest but their important application in various fields. Recently utilization of iron oxide based nanomaterials with novel property and functionality is widely studied due to their small size, high surface area, and magneti property $[23,24]$. Synthesis of iron oxide nanoparticles has been extensively reviewed [23-26]. Iron oxide nanoparticles are synthesized 


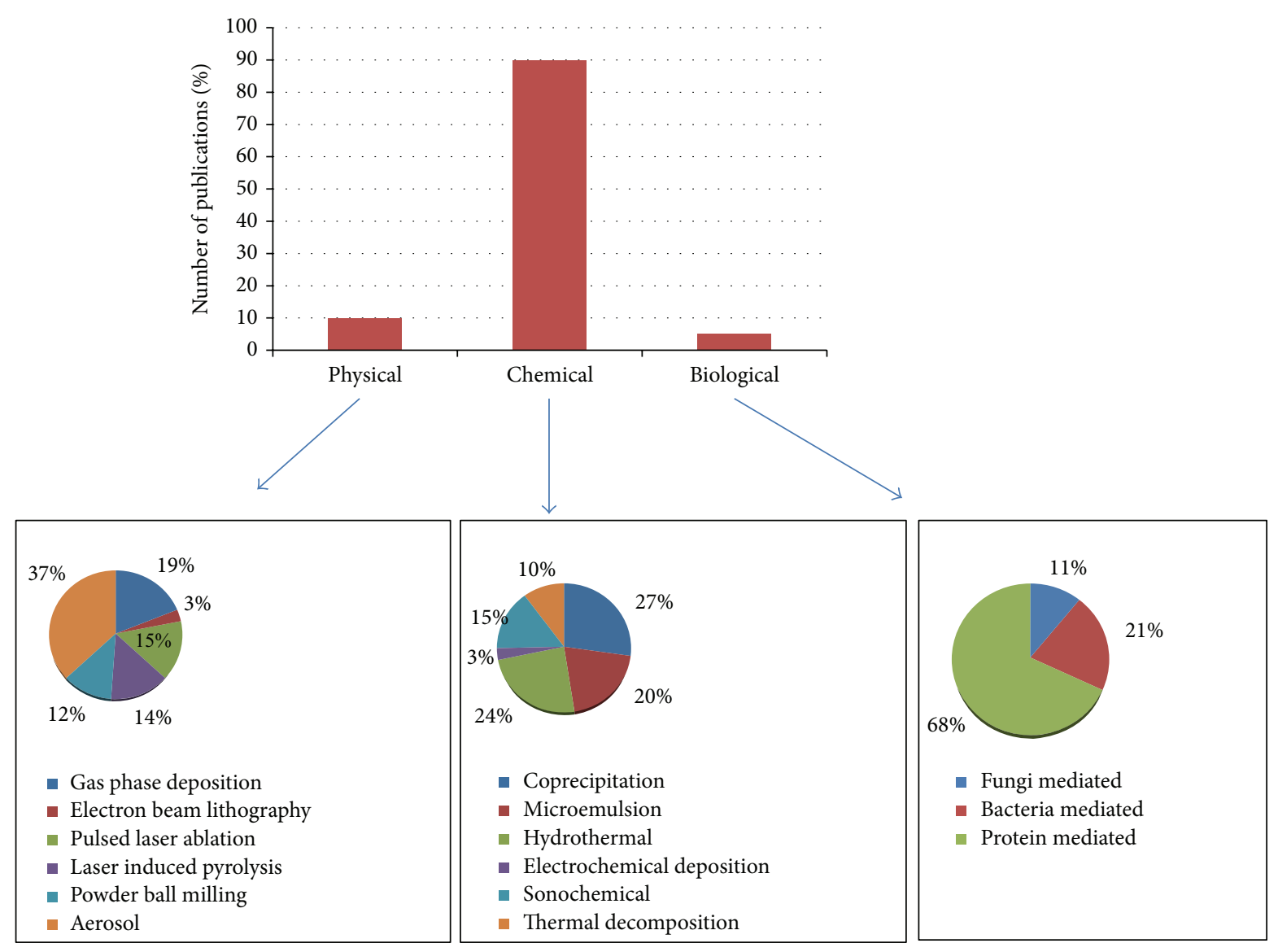

FIGURE 1: Synthesis of iron oxide nanoparticles by three different methods (adapted from [26]).

by three important methods such as physical, chemical, and biological as represented in the Figure 1. Chemical methods are well known and widely accepted methods for bulk production of iron oxide nanaparticles. There are many chemical methods such as chemical co-precipitation, thermal decomposition, sol-gel, electrochemical that have been reported in the literature which are shown in the Figure 1. Discussion of all synthetic methodologies in detail is the out of scope of this review. Concise overviews about synthetic methodology of IONPs are described here. Chemical coprecipitation method is a widely applicable method for synthesis of IONPs [27]. The chemical coprecipitation method involves the stoichiometric mixture of ferrous and ferric salts in ratio $2: 1\left(\mathrm{Fe}^{3+} / \mathrm{Fe}^{2+}\right)$ in aqueous medium in the presence of base and absence of oxygen. Formation of $\mathrm{Fe}_{3} \mathrm{O}_{4}$ is shown in (1) which is complete at a $\mathrm{pH}$ between 8 and 14. In the presence of oxygen and acid magnetite nanoparticles are converted into magnetite nanoparticles. The main advantage of this approach is that it produces a large amount of material, with control over particle size $(2-20 \mathrm{~nm})$ and shape afforded by adjusting $\mathrm{pH}$, ionic strength, and the concentration of solution. In the thermal decomposition method iron oleate can be performed from the decomposition of the iron precursor such as $\mathrm{Fe}(\mathrm{Cup})_{3}$, $\mathrm{Fe}(\mathrm{CO})_{5}$, and $\mathrm{Fe}(\mathrm{acac})_{3}$ in the organic solvent and surfactants at high temperature. The main advantage of thermal decomposition method is that, it improves control over the size and shape of iron oxides nanoparticles. The size and shape of iron oxides nanoparticles depend on the precursor and temperature $[28,29]$. Hydrothermal involves iron precursors in water by applying high pressure and temperature. The reactions are carried out in the reactors or autoclaves. In hydrothermal condition, nanoparticles were formed by hydrolysis and oxidation followed by neutralization of mixed metal hydroxides. Ferromagnetic $\mathrm{Fe}_{3} \mathrm{O}_{4}$ NPs with diameter of $27 \mathrm{~nm}$ have been synthesized by a hydrothermal route in the presence of a surfactant sodium bis(2-ethylhexyl)sulfosuccinate [30]. Aqueous ferrofluid iron oxides nanoparticles synthesized by hydrothermal method using citric acid as reducing agent. The particles size are about $8 \mathrm{~nm}$ [31]. Surface modification of IONPs by polyethyleneimine was also prepared by hydrothermal method [32]. Others methods to prepare iron oxide nanoparticles are described in Table 1.

Consider

$$
\mathrm{Fe}^{+2}+2 \mathrm{Fe}^{+3}+8 \mathrm{OH}^{-} \longrightarrow \mathrm{Fe}_{3} \mathrm{O}_{4}
$$

To understand the behavior of colloidal ferrofluid particles and improve their application carefully studied related to their fluid stability are necessary. Iron oxide nanoparticles are easily subject to aggregation in aqueous system and biological system. IONPs exhibit the hydrophilic surface due to presence of hydroxyl groups. There is hydrophilic interaction between particles and these particles form the 
TABLE 1: Various chemical methods for synthesis of iron oxide nanoparticles.

\begin{tabular}{|c|c|c|c|}
\hline Name of method & Preparation method & Advantage & References \\
\hline Microemulsion & $\begin{array}{l}\text { Iron salt and base solution are mixed together } \\
\text { which disperse in oil phase by adding surfactant }\end{array}$ & $\begin{array}{l}\text { Diversity of iron oxide nanoparticles is prepared } \\
\text { by varying the nature and concentration } \\
\text { surfactant and reaction condition }\end{array}$ & [45-47] \\
\hline Polyols method & $\begin{array}{l}\text { Iron salt solvent dissolves in the polyols solvent. } \\
\text { The suspension is stirred and heats up to boiling } \\
\text { point of solvent. Polyols act as reducing as well as } \\
\text { stabilizer }\end{array}$ & $\begin{array}{l}\text { Control of particle growth and prevention of } \\
\text { interparticle aggregation and obtaining } \\
\text { well-defined shape and control size of particles }\end{array}$ & {$[48-50]$} \\
\hline Sonolysis & $\begin{array}{l}\text { Organometallic precursors decomposed by } \\
\text { sonolysis }\end{array}$ & High magnetization and crystallinity achievement & [51-53] \\
\hline Gas-aerosol & $\begin{array}{l}\text { Ferric salts and a reducing agent in organic solvent } \\
\text { are sprayed into a series of reactors and aerosol } \\
\text { solute condenses and evaporation of solvent }\end{array}$ & $\begin{array}{l}\text { Different size and shape of particles were prepared } \\
\text { by using different iron precursors }\end{array}$ & {$[54-56]$} \\
\hline Sol-gel & $\begin{array}{l}\text { Hydroxylation and condensation of molecular } \\
\text { precursors in solution are known as "sol," while } \\
\text { evaporation of solvent to form three-dimensional } \\
\text { network of nanoparticles is called "gel" }\end{array}$ & $\begin{array}{l}\text { Control of particles size and stability of particles } \\
\text { in sol-gel matrix }\end{array}$ & {$[57]$} \\
\hline $\begin{array}{l}\text { Electrochemical } \\
\text { decomposition }\end{array}$ & $\begin{array}{l}\text { Iron oxide nanoparticles produce by oxidation of } \\
\text { iron electrode in aqueous solution }\end{array}$ & Particles size control by adjusting current density & {$[58-60]$} \\
\hline
\end{tabular}

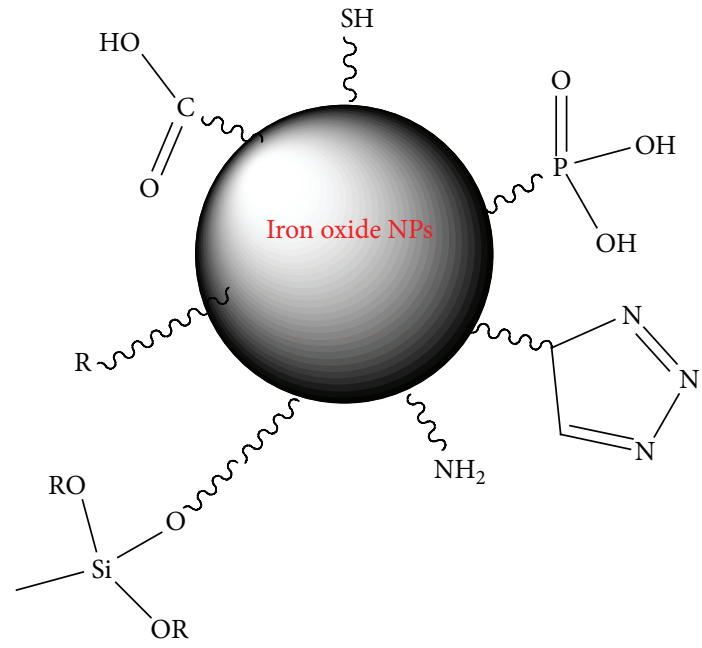

FIGURE 2: Schematic representation of surface modification of iron oxide nanoparticles.

agglomerate and resulted in large clusters. For stability among nanoparticles there is balance between attractive and repulsive force acting between nanoparticles [24]. To overcome this problem, there is requirement of electronic and steric stability of IONPs. Presence of hydroxyl groups on the surface of IONPs provides a versatile synthetic tool to attach different functionalities. Surface modification methodologies of IONPs improved the stability and provide novel proprieties to materials. The stabilization of the iron oxide particles is so important to produce magnetic colloidal "ferrofluids." These ferrofluids are stable against aqueous, biological medium and magnetic field. Modified magnetic nanoparticles have numerous applications in biomedical such as drug delivery, magnetic resonance imaging, hyperthermia, cellular labeling, protein separation, and remediation of environment. There are different methodologies that have been reported for fabrication of INOPs as represented in Figure 2. Attachment of alkoxysilane to the surface of IONPs using different silane coupling agents is the most common surface modification technique. Organosilane is an attractive reagent for surface modification of nanoparticles because of an easy commercial availability, a simple synthetic method to immobilize on the surface of nanoparticles, and providing variety of functionality. Si-OR group of silane react with surface hydroxyl group of IONPs [33-35]. It is the hydrolysis and condensation reaction. By using trialkoxy silane functional group help to introduce various functionality such as amine, azide, aldehyde, thio, halide, hydroxyl, and acid on the surface of IONPs. Silane coupling agent further provides versatile tools to attach small organic molecules, polymers, and biomolecules to the surface. INOPs surface modifies by PEG using APS [36]. Molecular weight of PEG more than $1000 \mathrm{gm} / \mathrm{mL}$ formed the stable nanoparticles. Magnetic nanoparticles are coated with silane-PEG. Oleic acid on the surface of IONPs replaced by biocompatible silane PEG polymer for magnetic resonance imaging of murine tumors [37]. Ahangaran et al. reported the surface modification of magnetic nanaparticles by coating of silica. The hydrophilic nature of nanoparticles easily aggregate. Vinyltriethoxysilane acts as a coupling agent which provides hydrophobicity to the surface and decrease the agglomerations [38]. Immobilization of cyanoethyl triethoxysilane on the surface of $\mathrm{Fe}_{3} \mathrm{O}_{4}$. Cyano group on the surface stabilizes the magnetite nanoparticles and also improves the cellular labeling and the cell targeting [39]. Click chemistry is also an important method to modify INOPs. Click reaction such as azide-alkyne, thio-ene, thio-yne, and diels-alder is used for modification of the surface of magnetic nanoparticles. Oligonucleotides immobilized on the surface of SPINOs. There is azide-alkyne copper that mediates click reaction between oligonuclotides bearing alkyne with using alkyne 
NHS-ester reagent and azide functional group on the surface of SPINOs. These nanoparticles can easily cross the HeLa cell membranes without using transfection agents as compared to their Au analogues [40]. Surface of SPINOs modifies by copolymers of poly(glycidyl methacrylate-co-poly(ethylene glycol) methyl ether methacrylate using atom transfer-free radical polymerization (ATRP) and introduces folic acid (FA) via azide-alkyne click reaction and they stabilize in the water so as to prolong in vivo circulation time [41]. SPIONs-P(GMA-co-PEGMA)-FA prepared by combination of ATRP and click chemistry can potentially be a good candidate for enhancing the targeting efficiency of cancer cells [42]. SPIONs-loaded cisplatin an anticancer drug conjugated to amphiphilic poly( $\varepsilon$-caprolactone)- $b$-poly-(propargyl methacrylate-click-mercaptosuccinic acid-co-poly-(ethylene glycol) methyl ether methacrylate) (PCL-b-P-(PMA-clickMSA-co-PEGMA) was synthesized by a combination of ROP, RAFT polymerization and thiol-yne click chemistry [43]. These are potential drug delivery systems of cisplatin for bladder cancer therapy. Hyper branch polyethylene glycol attached to surface of magnetic nanoparticles by using thioene click reaction is useful for active targeting anticancer agents [44].

\section{Arsenic Removal by Using Iron Oxide Nanaparticles and Their Nanomaterials}

Water contamination by arsenic salt is one of the big environmental pollution. It causes life time diseases such as cancer, neurological disorder, nausea, hyperkeratosis, muscular weakness, and many others [74]. Arsenic contamination in drinking water has been found domestically which can be led to numerous diseases. It was reported by world health organization in 2006 that around 45-57 million people in Bangladesh and 13 million people in United States have been exposed to unsafe arsenic contaminated water [75]. As per guide lines of USEPA, maximum contaminant level of arsenic in the drinking water should be $0.010 \mathrm{ppm}$ [76]. It is therefore necessary to have an effective method to remove arsenic from the natural water and waste water. Iron oxides nanoparticles have shown prominent result for decontamination of arsenic from the water [77-79]. So they could become cost-effective materials for decontamination of arsenic from the water. Magnetite, hematite, and maghemite nanoparticles are synthesized by various chemical methods to remove $\mathrm{As}(\mathrm{III})$ and $\mathrm{As}(\mathrm{V})$ from water as presented in Table 2. The small size and high surface area of magnetite nanoparticles make them and ideal adsorbent. Heavy metals in the solution easily diffuse on the active surface of $\mathrm{Fe}_{3} \mathrm{O}_{4}$ nanoparticles. Surface area of magnetic nanoparticles plays a significant role in the adsorption process. The high surface nanoparticles can easily undergo aggregation in the solution which could decrease their efficiency so it is important to modify the surface of IONPs for improving their activity. Surface of iron oxides nanoparticles can be modified by the attachment with suitable functional groups such as carboxylic acids, phosphoric acid, silanol, thio, and amine as well as small organic molecules, biomolecules, polymer, and other metal nanoparticles as represented in Figure 2. Feng et al. synthesized supermagnetic ascorbic acidcoated $\mathrm{Fe}_{3} \mathrm{O}_{4}$ by hydrothermal method. These nanocomposites have a diameter less than $10 \mathrm{~nm}$ and surface area about $179 \mathrm{~m}^{2} / \mathrm{g}$. The ascorbic acid-coated $\mathrm{Fe}_{3} \mathrm{O}_{4}$ shows super paramagnetic property at room temperature and saturation magnetization approaches $40 \mathrm{emug}^{-1}$ and they are employed as an adsorbent to remove arsenic from the waste water. The maximum adsorption capacity of $\mathrm{As}(\mathrm{V})$ and $\mathrm{As}$ (III) is $16.56 \mathrm{mg} / \mathrm{g}$, and $46.06 \mathrm{mg} / \mathrm{g}$, respectively, as followed by Langmuir isotherm [80]. Formation of $\mathrm{Fe}_{2} \mathrm{O}_{3}$ nanoparticles in the matrix of cellulose has been reported by one pot chemical co-precipitation method [81]. The surface area of these nanocomposites is $113 \mathrm{~m}^{2} / \mathrm{g}$. They are demonstrated for the removal of arsenic from aqueous solution. They showed excellent adsorption capacity to remove As(III) and As(V) 23.16, 32.11, 9.64, and $3.25 \mathrm{mg} / \mathrm{g}$ followed by Langmuir and Freundlich isotherm, respectively. $\beta$-Cyclodextrin $(\mathrm{CM} \beta \mathrm{CD})$-monodisperse magnetite nanoparticles with average nanoparticles size $10 \mathrm{~nm}$ are prepared by thermal decomposition and postgrafting methodology [82]. These CMCD$\mathrm{Fe}_{3} \mathrm{O}_{4}$ are used to remediate of As(III), As(V), 2-naphthol, and naphthalene. $\mathrm{Fe}_{2} \mathrm{O}_{3}$ chestnut-like amorphous-core $/ \gamma$ phase shell hierarchical nanostructure that showed the strong adsorption of As(V). It adsorbed $143.12 \mathrm{~m}^{2} / \mathrm{g}$ of $\mathrm{As}(\mathrm{V})$ [83]. There are numerous applications of magnetic nanomaterial to remove arsenic salts from water that are summarized in Table 3.

\section{Removal of Copper and Chromium and Chromium Metal}

Copper has enormous application in the industry. It is used in the electroplating, paint and pigment industry, electrical, and fertilizer. Due to wide range of application of copper can be accumulated in the environment which makes water more pollute. Surface modification of magnetite nanoparticles is by ligand 1; 6hexadiamine has been reported [84]. This is useful for removal of $\mathrm{Cu}$ (II) from aqueous system. Magnetic nanoparticles bearing amine group on their surface were able to remove $98 \%$ copper from polluted river and tap water. The equilibrium is achieved within five minutes and kinetics followed the pseudosecond order mechanism. The maximum adsorption capacity was $25.77 \mathrm{mg} / \mathrm{g}$ at $\mathrm{pH}$ 6 and $298 \mathrm{~K}$. Amine functional group also immobilized on the surface of silica coated magnetic nanoparticles by 3-aminopropyltriethoxysilan using sol-gel method. The adsorption capacity of magnetic nanoparticles that exhibit amine group is $22.4 \mathrm{mg} / \mathrm{g}$ [85]. In the above case magnetic nanoparticles having amine functionality on the surface lead to an increase in adsorption capacity which increases with $\mathrm{pH}$. At lower $\mathrm{pH}$, amine group undergoes protonation which decreases adsorption efficiency; however, at higher $\mathrm{pH}$ strong complexation takes place between $\mathrm{Cu}^{+2}$ and free amine group. Banerjee and $\mathrm{Chen}$ reported $\mathrm{Fe}_{3} \mathrm{O}_{4}$-gum-arabic nanocomposite for removal of $\mathrm{Cu}(\mathrm{II})$. Gum arabic attach to surface of $\mathrm{Fe}_{3} \mathrm{O}_{4}$ via coupling between surface hydroxyl group 
TABLE 2: Application of iron oxides nanaparticles for removal of arsenic according to the Langmuir isotherm.

\begin{tabular}{|c|c|c|c|c|c|c|}
\hline Name of IONPs & Method of synthesis & $\begin{array}{l}\text { Size } \\
(\mathrm{nm})\end{array}$ & $\begin{array}{c}\text { BET surface area } \\
\mathrm{m}^{2} / \mathrm{g}\end{array}$ & $\begin{array}{l}\text { Sorption capacity } \\
\text { of As (III) mg/g }\end{array}$ & $\begin{array}{c}\text { Sorption capacity } \\
\text { of As }(\mathrm{V}) \mathrm{mg} / \mathrm{g}\end{array}$ & References \\
\hline$\gamma-\mathrm{Fe}_{2} \mathrm{O}_{3}$ & $\begin{array}{c}\text { Chemical } \\
\text { coprecipitation }\end{array}$ & $7-12$ & 168.73 & $67.02\left(30^{\circ} \mathrm{C}\right)$ & $95.37\left(350^{\circ} \mathrm{C}\right)$ & {$[61]$} \\
\hline $\mathrm{Fe}_{3} \mathrm{O}_{4}$ & $\begin{array}{l}\text { Chemical } \\
\text { coprecipitation }\end{array}$ & 17 & - & $8.2^{\mathrm{a}}$ and $5.68^{\mathrm{b}}$ & $6.71^{\mathrm{a}}$ and $4.78^{\mathrm{b}}$ & {$[62]$} \\
\hline$\alpha-\mathrm{Fe}_{2} \mathrm{O}_{3}$ & $\begin{array}{c}\text { Chemical } \\
\text { coprecipitation }\end{array}$ & 12 & - & $1.25^{\mathrm{a}}$ and $20^{\mathrm{b}}$ & $4.6^{\mathrm{a}}$ and $4.9^{\mathrm{b}}$ & {$[62]$} \\
\hline$\alpha-\mathrm{Fe}_{2} \mathrm{O}_{3}$ & Solvent thermal & 5 & 162 & 95 & 47 & {$[63]$} \\
\hline$\gamma-\mathrm{Fe}_{2} \mathrm{O}_{3}$ & Wet chemical & 4 & 100 & - & 45 & {$[64]$} \\
\hline $\begin{array}{l}\text { Magnetite }(55.8 \%) \text { and } \\
\text { Maghemite }(44.2 \%)\end{array}$ & Iron wires & 34 & 12 & 2.9 & 3.05 & {$[65]$} \\
\hline
\end{tabular}

${ }^{\mathrm{a}} 1 \mathrm{~h}$ contact time, ${ }^{\mathrm{b}} 24 \mathrm{~h}$ contact time.

TABLE 3: Overview of various iron oxide nanomaterials for removal of arsenic.

\begin{tabular}{|c|c|c|c|c|}
\hline \multirow{2}{*}{ Adsorbents } & \multirow{2}{*}{ BET surface area $\left(\mathrm{m}^{2} / \mathrm{g}\right)$} & \multicolumn{2}{|c|}{ Adsorption capacity $(\mathrm{mg} / \mathrm{g})$} & \multirow{2}{*}{ References } \\
\hline & & As (III) & As $(V)$ & \\
\hline Magnetite-silica & 163.54 & - & 170 & {$[66]$} \\
\hline $\mathrm{MnFe}_{2} \mathrm{O}_{4}$ & 138 & 93.8 & 90.4 & {$[67]$} \\
\hline $\mathrm{CoFe}_{2} \mathrm{O}_{4}$ & 101 & 100.3 & 73.8 & {$[67]$} \\
\hline Magnetic-graphene & 148 & 13.10 & 5.83 & {$[68]$} \\
\hline $\mathrm{Fe}_{3} \mathrm{O}_{4}-\mathrm{BC}$ cellulose & & - & 36.9 & [69] \\
\hline Mesoporous $\mathrm{Fe}_{2} \mathrm{O}_{3} @ \mathrm{C}$ & 877 & 29.4 & 17.9 & {$[70]$} \\
\hline Magnetic binary oxide nanoparticles & 123.8 & 23.25 & - & {$[71]$} \\
\hline $\mathrm{Fe}_{3} \mathrm{O}_{4}$ wheat saw & & 3.9 & 8.06 & {$[72]$} \\
\hline $\mathrm{MI} / \mathrm{CNTs}$ & 662.1 & 8.13 & 9.74 & {$[73]$} \\
\hline
\end{tabular}

of nanoparticles and carboxylic acid group of GA. The average diameter of particles are in range of $13-67 \mathrm{~nm}$ and $5.1 \mathrm{wt} \%$ of arabic gum was immobilized. The adsorption rate is so fast and equilibrium was achieved within $2 \mathrm{~min}$. It showed that chemical adsorption takes place and strong complexation between $\mathrm{Cu}(\mathrm{II})$ and amine group of arabic gum. The zeta potential value increased with decrease in $\mathrm{pH}$ of solution due to protonation of hydroxyl group of nanoparticles and carboxylic acid and amine of GA. The effect of $\mathrm{pH}$ on adsorption is also investigated at $\mathrm{pH}<2$ no adsorption took place. At $\mathrm{pH} 2-6$ adsorption increases with increase in $\mathrm{pH}$. The adsorption capacity of magnetic nanoparticles and GAMNP is 17.6 and $38.5 \mathrm{mg} / \mathrm{g}$, respectively, which is followed Langmuir isotherm. GA-MNP regenerated by using acid solution. The GA-MNP exhibits good reusability. The adsorption capacity of GA-MNP was 28.12, 27.64, and $27.18 \mathrm{mg} / \mathrm{g}$ in first, second, and third adsorption-desorption cycles, respectively [86]. Chitosan coated maghemite nanoparticles were modified with a biodegradable and ecofriendly reagent $\alpha$-ketoglutaric acid and demonstrated for removal of $\mathrm{Cu}$ (II) from water [87]. These magnetic based nanoadsorbents were also characterized by XRD, FT-TR, TEM, VSM, and EDS. The particles size of CCMNPs bearing $\alpha$-ketoglutaric acid is about $30 \mathrm{~nm}$. In FT-IR spectra characteristic peak around $589 \mathrm{~cm}^{-1}$ indicates successful coating of $\gamma-\mathrm{Fe}_{2} \mathrm{O}_{3}$. Another characteristic peak of magnetic CCMNPs around $1644 \mathrm{~cm}^{-1}$ shows vibration of primary amine which disappears after immobilization of $\alpha$-ketoglutaric acid and new peak around $1618 \mathrm{~cm}^{-1}$ is the vibration peak of secondary amine that also confirmed coating of $\alpha$-ketoglutaric acid to magnetic CCMNPs. The other bands are $1402 \mathrm{~cm}^{-1}$ and $1718 \mathrm{~cm}^{-1}$ of $\mathrm{C}-\mathrm{H}$ stretching vibration of $\mathrm{CH}_{2}$ from $\alpha$-ketoglutaric acid and amide functional group, respectively. $\gamma-\mathrm{Fe}_{2} \mathrm{O}_{3}$ confirmed from XRD pattern. XRD becomes broader and lower indicating that KA modifies uniformly CCMNPs. The saturation magnetization of KA-CCMNPs is $33.5 \mathrm{emu} / \mathrm{g}$ which showed that they are super magnetic in nature and very susceptible to the external magnetic field. The adsorption data showed following Langmuir isotherm and maximum capacity of $\mathrm{Cu}$ (II) removal were $96.15 \mathrm{mg} / \mathrm{g}$. Chitosan supported on the surface of magnetite nanoparticles. First chitosan carboxymethylated was prepared after that it was covalently attached to the $\mathrm{Fe}_{3} \mathrm{O}_{4}$ nanoparticles surface. They were employed for removal of $\mathrm{Cu}$ (II). The maximum adsorption capacity is $21.5 \mathrm{mg} / \mathrm{g}$ which followed Langmuir equation. The effect of $\mathrm{pH}$ and temperature was also demonstrated. The adsorption capacity increases with increase in $\mathrm{pH}$ [88]. Magnetic composite microspheres bearing of $\mathrm{Fe}_{3} \mathrm{O}_{4}$ nanoparticles and polyacrylic acid-chitosan were prepared by chemical coprecipitation method as an efficient adsorbent for removal of $\mathrm{Cu}$ (II) [89]. The CS/PPA- $\mathrm{Fe}_{3} \mathrm{O}_{4}$ microspheres have been exhibited higher adsorption capacity than $\mathrm{CS}-\mathrm{Fe}_{3} \mathrm{O}_{4}$ microspheres. The $\mathrm{Fe}_{3} \mathrm{O}_{4}$-polyvinyl acetate-iminodiacetic acid contains EDTA and was also useful adsorbent for removal 
of $\mathrm{Cu}(\mathrm{II})$ [90]. Carboxymethyl- $\beta$-cyclodextrin modified with magnetite nanoparticles $\left(\mathrm{CM} \beta \mathrm{CD}-\mathrm{Fe}_{3} \mathrm{O}_{4}\right)$ are the efficient magnetic adsorbents for the detoxification of copper ions from the water. $\mathrm{CM} \beta \mathrm{CD}$ grafted on the surface of magnetic nanoparticles by carbodiimide method. The high efficiency of this magnetic adsorbent is due to presence of multiple hydroxy and carboxyl groups. The adsorption of $\mathrm{Cu}(\mathrm{II})$ onto $\mathrm{CM} \beta \mathrm{CD}-\mathrm{MNPs}$ was found to be dependent on $\mathrm{pH}$ and temperature [91]. Magnetic-grapheme nanocomposites are reported by one pot thermal decomposition method. It is an efficient nanomaterial for removal of $\mathrm{Cr}(\mathrm{VI})$ from the waste water at low $\mathrm{pH}$ that it removed $\mathrm{Cr}(\mathrm{VI})$. The large saturation magnetization $(96.3 \mathrm{emu} / \mathrm{g})$ of the synthesized nanoparticles allows fast separation of the adsorbent. Recycling process is more energetically and economically sustainable. The significantly reduced treatment time required to remove the $\mathrm{Cr}(\mathrm{VI})$ and the applicability in treating the solutions with low $\mathrm{pH}$ makes magnetic-graphene adsorbent promising for the efficient removal of heavy metals [92]. Montmorillonite supported $\mathrm{Fe}_{3} \mathrm{O}_{4}$ nanoparticles exhibited good adsorption capacity than $\mathrm{Fe}_{3} \mathrm{O}_{4}$ for removal of $\mathrm{Cr}(\mathrm{VI})$ [93]. The high efficiency is due to montmorillonite possessed porosity which provides better dispersion of magnetite nanaparticles inside and less aggregation. The Magnetic nanaparticles supported on organ peel pith by using redox precipitation method. These nanaparticles have the $20 \times 80 \mathrm{~nm}$ tubular shapes and octahedral crystals around $20-40 \mathrm{~nm}$. It showed higher adsorption capacity than unmodified magnetic nanaparticles towards the removal of $\mathrm{Cr}(\mathrm{VI})$ [94]. Magnetite-polypyrrole composite microspheres have been synthesized using $\mathrm{Fe}_{3} \mathrm{O}_{4}$ microspheres as a chemical template under sonication. $\mathrm{Fe}_{3} \mathrm{O}_{4} / \mathrm{PPy}$ have a strong adsorption capacity for $\mathrm{Cr}(\mathrm{VI})$ with a maximum adsorption capacity of about $209.2 \mathrm{mg} / \mathrm{g}$ [95].

\section{Removal of Other Heavy Metals}

$\mathrm{Fe}_{3} \mathrm{O}_{4}$ nanoadsorbents have been demonstrated for the removal of $\mathrm{Pb}(\mathrm{II})$ ions from aqueous solution using a batch-adsorption technique. The effect of temperature, $\mathrm{pH}$, and coexisting ions on the adsorption of $\mathrm{Pb}(\mathrm{II})$ has been studied in detail. Adsorption equilibrium was achieved within $30 \mathrm{~min}$. The amount of $\mathrm{Pb}(\mathrm{II})$ adsorbed increases with increasing temperature that indicates endothermic adsorption as well as there is no effect of coexisting cation on the adsorption. The adsorption equilibrium data followed the Langmuir and Freundlich adsorption isotherm models. The thermodynamics of $\mathrm{Pb}(\mathrm{II})$ adsorption onto the $\mathrm{Fe}_{3} \mathrm{O}_{4}$ nanoadsorbents suggest that the adsorption was spontaneous, endothermic, and physical in nature. The maximum adsorption capacity of $\mathrm{Pb}$ is $36 \mathrm{mg} / \mathrm{g}$ [96]. Maghemite $\left(\gamma-\mathrm{Fe}_{2} \mathrm{O}_{3}\right)$ nanoparticles for the selective removal of toxic heavy metals from electroplating wastewater. The maghemite nanoparticles of $60 \mathrm{~nm}$ were synthesized using a co-precipitation process. It was characterized by XRD and $\mathrm{EDX}$. The adsorption of $\mathrm{Pb}(\mathrm{II})$ attained equilibrium within $15 \mathrm{~min}$. The adsorption of $\mathrm{Pb}(\mathrm{II})$ increases with increase in the $\mathrm{pH}$ [97]. MNPs-Ca-alginate coated with Phanerochaete chrysosporium adsorbed about $90 \%$ of $\mathrm{Pb}(\mathrm{II})$ after repeated five cycles [98] and reactive blue-19 dye on the surface of magnetic nanaparticles also an efficient adsorbent for decontamination of $\mathrm{Pb}$ (II) [99]. Water soluble magnetite nanoparticles prepared by hydrothermal method with high solubility and stability showed high affinity for $\mathrm{Pb}(\mathrm{II})$ and $\mathrm{Cr}(\mathrm{VI})$ than water insoluble magnetite nanoparticles [100]. This water soluble magnetic nanoparticles have the capacity to remove $90 \%$ of $\mathrm{Pb}$ (II) in $2 \mathrm{~min}$. The high value of saturation magnetization $(83.4 \mathrm{emu} / \mathrm{g})$ can easily remove from the aqueous system. Flower- and hollow-like nest morphology of $\alpha-\mathrm{Fe}_{2} \mathrm{O}_{3}$ nanoparticles was prepared by template-free solvent thermal method and glycerol mediated microwaveassisted methods $[101,102]$. They were useful for removal of $\mathrm{As}(\mathrm{V})$ and $\mathrm{Cr}(\mathrm{V})$ from the water. The maximum adsorption capacity of 51 and $30 \mathrm{mg} / \mathrm{g}$ for the $\mathrm{As}(\mathrm{V})$ and $\mathrm{Cr}(\mathrm{V})$ on flower-like magnetic adsorbent, respectively, while 75.3 and $58.5 \mathrm{mg} / \mathrm{g}$ for the $\mathrm{As}(\mathrm{V})$ and $\mathrm{Cr}(\mathrm{V})$ on hollow nest-like magnetic adsorbent. Maghemite nanotubes were synthesized by microwave irradiation method. It was used as nanoadsorbent to detoxify heavy metals such as $\mathrm{Cu}(\mathrm{II}), \mathrm{Zn}(\mathrm{II})$, and $\mathrm{Pb}(\mathrm{II})$. The BET surface area was found to be $321.638 \mathrm{~m}^{2} / \mathrm{g}$ and magnetic saturation was emu/g. From the Langmuir isotherms, the maximum adsorption capacities of tubular maghemite adsorbents towards $\mathrm{Cu}(\mathrm{II}), \mathrm{Pb}(\mathrm{II})$, and $\mathrm{Zn}$ (II) were 111.11, 71.42, and $84.95 \mathrm{mg} / \mathrm{g}$, respectively. The kinetic data of adsorption of heavy metal ions on the synthesized nanoadsorbents were followed by a pseudosecond-order equation indicating their chemical adsorption [103]. Multiwall carbon nanotube-magnetite nanocomposites based magnetic nanoadsorbent were prepared. Thiol functional group was anchored on the surface of $\mathrm{CNTs} / \mathrm{Fe}_{3} \mathrm{O}_{4}$ using 3mercaptopropyltriethoxysilane [104]. The BET surface area of these adsorbent is $97.16 \mathrm{~m}^{2} / \mathrm{g}$. The maximum Langmuir adsorption capacity for removal of $\mathrm{Pb}$ and $\mathrm{Hg}(\mathrm{II})$ is 65.40 and $65.52 \mathrm{mg} / \mathrm{g}$, respectively. Surface of $\mathrm{Fe}_{3} \mathrm{O}_{4}$ modified with 2-mercaptobenzthiazole is an efficient adsorbent for removal of toxic metal $\mathrm{Hg}(\mathrm{II})$ than unmodified magnetic nanoparticles. Unmodified nanaparticles are able to remove $43.47 \%$ of $50 \mathrm{ng} / \mathrm{mL}$ of $\mathrm{Hg}$ (II) from polluted water while modification with MBT improved the removal efficiency up to $98.6 \%$ in the same concentration within $4 \mathrm{~min}$. There is no considerable effect on adsorption efficiency by variation of $\mathrm{pH}$ and electrolyte $\mathrm{NaCl}$ concentration [105]. Amine functionalize magnetite nanaparticles are useful adsorbent for decontamination of heavy metals such as lead, copper, and cadmium. AF- $\mathrm{Fe}_{3} \mathrm{O}_{4}$ prepared by hydrothermal method in which iron salt $\mathrm{FeCl}_{3} \cdot 6 \mathrm{H}_{2} \mathrm{O}$ was added to ethylene glycol followed by sodium acetate and ethanediamine and sealed in teflon lined stainless-steel autoclave heat at $200^{\circ} \mathrm{C}$ temperature for $8 \mathrm{~h}$. The morphology of $\mathrm{AF}-\mathrm{Fe}_{3} \mathrm{O}_{4}$ was investigated by transmission electron microscopy. The mesoporous morphology has been observed in TEM picture. The pore volume and BET surface are $0.1833 \mathrm{~cm}^{3} / \mathrm{g}$ and $25.94 \mathrm{~m}^{2} / \mathrm{g}$, respectively ray diffraction pattern proved that it is magnetite phase structure. The zeta-potential value decreased with increase of $\mathrm{pH}$. The adsorption rate of $\mathrm{AF}-\mathrm{Fe}_{3} \mathrm{O}_{4}$ follows pseudosecond-order kinetic model. The equilibrium was achieved within $120 \mathrm{~min}$ at $\mathrm{pH}$ 7. According to Langmuir 
isotherm, the maximum adsorption capacity for $\mathrm{Pb}(\mathrm{II})$, $\mathrm{Cd}(\mathrm{II})$, and $\mathrm{Cu}(\mathrm{II})$ is $369,446.4$, and $523 \mathrm{mg} / \mathrm{g}$, respectively. AF- $\mathrm{Fe}_{3} \mathrm{O}_{4}$ adsorbent is endothermic and spontaneous [106]. The surface functionalization of magnetic nanoparticles by copolymer of acrylic acid and crotonic acid which further modify with 3-aminopropyltroethoxysilane are the efficient adsorbent to detoxification of heavy metals such as $\mathrm{Cu}, \mathrm{Pb}$, $\mathrm{Zn}$, and $\mathrm{Cd}(\mathrm{II})$ from the aqueous solution. The maximum adsorption capacities of these metals are 126.9, 166.1, 43.4, and $29.6 \mathrm{mg} / \mathrm{g}$, respectively [107]. Humic acid coated magnetite nanaparticles were prepared by coprecipitation method. The saturation magnetization of $79.6 \mathrm{emu} / \mathrm{g}$ of $\mathrm{Fe}_{3} \mathrm{O}_{4}$ - $\mathrm{HA}$ enables easy separation from the water at low magnetic field within a few minutes. The equilibrium reached in less than $15 \mathrm{~min}$ and Langmuir isotherm with maximum adsorption capacity was from 46.3 to $97.7 \mathrm{mg} / \mathrm{g}$. They are stable in tap and natural water and acidic/basic solutions ranging from $0.1 \mathrm{M} \mathrm{HCl}$ to $2 \mathrm{M} \mathrm{NaOH}$ with leaching of $\mathrm{Fe}<3.7 \%$ and humic acid $<$ $5.3 \% . \mathrm{Fe}_{3} \mathrm{O}_{4}$-HA was able to remove more than $99 \%$ of $\mathrm{Hg}$ and $\mathrm{Pb}(\mathrm{II})$ and $95 \%$ of $\mathrm{Cu}(\mathrm{II})$ and $\mathrm{Cd}(\mathrm{II})$ in natural and tap water [108]. Surface modifications of $\mathrm{Fe}_{3} \mathrm{O}_{4}$ with succinic acid, ethylenediamine, and 2,3-dimercaptosuccinic acid have been reported [109]. The TEM image of the above mentioned acid and thiol functional group supported to surface of $\mathrm{Fe}_{3} \mathrm{O}_{4}$ demonstrated formation of spherical nanaparticles with average sizes of carboxylic acid and thiol group are $10 \mathrm{~nm}$ and $6 \mathrm{~nm}$, respectively, while amine functionalization shows the well-define and discrete morphology with mesoporous in nature. The average size of amine functionalize to magnetic nanoparticles is $40 \mathrm{~nm}$ and an average diameter is about of $6 \mathrm{~nm}$. From the IR-spectra a strong vibration peak at $588 \mathrm{~cm}^{-1}$ in all three functionalized groups of magnetic nanoparticles assigned to stretching vibration of $\mathrm{Fe}-\mathrm{O}$. The band at 1690 and $1700 \mathrm{~cm}^{-1}$ is due to carbonyl stretching vibration of succinic acid (SA) and 2,3-dimercaptosuccinic acid (DMSA) which shifted at lower value at 1620 and $1660 \mathrm{~cm}^{-1}$ after being supported to magnetic nanoparticles and the same observation was also reported in the case of $-\mathrm{NH}_{2}$ bending frequency in the spectra of ethylenediamine and amine- $\mathrm{Fe}_{3} \mathrm{O}_{4}$ spectra which confirms the immobilization of SA, DMSA, and EDA on the surface of magnetic nanoparticles. The $\mathrm{pH}$ of zero point charge of carboxyl-MNP and amine-MNP were found near about 4.5 and 4.7. The value of zeta potential of all three adsorbents is decreased with increase in $\mathrm{pH}$; thus surface of carboxyl MNP and amine MNP have positive surface charge at $\mathrm{pH}<\mathrm{pH}_{\mathrm{pzc}}$ and negative with $\mathrm{pH}>\mathrm{pH}_{\mathrm{pz}}$. The surface of thiol-MNP has negative surface charge in the range of $\mathrm{pH} 2-12$. The mean hydrodynamic diameters were about $25 \mathrm{~nm}, 90 \mathrm{~nm}$, and $17 \mathrm{~nm}$ for carboxyl, amine, and thiol MNP measured by DLS which indicated presence of hydrated organic layers. The carboxyl, amine and thiol groups are tightly bound on the surface of $\mathrm{Fe}_{3} \mathrm{O}_{4}$ which provide high stability in aqueous stability to magnetite nanoparticles. The saturation magnetization of carboxyl, thiol and amine MNP are found to be 59.5, 43.2, and $64.3 \mathrm{emu} / \mathrm{g}$, respectively. Such strong magnetic property enables to separate of three adsorbents easily from the solution. These three adsorbents are demonstrated for removal of heavy metals such as $\mathrm{Cr}(\mathrm{III}), \mathrm{Ni}(\mathrm{II}), \mathrm{Co}(\mathrm{II})$, $\mathrm{Cu}(\mathrm{II}), \mathrm{Cd}(\mathrm{II}), \mathrm{Pb}(\mathrm{II})$ and $\mathrm{As}(\mathrm{III})$. The removal efficiency increases with increase in the case that all three adsorbents are due to strong complexation that takes place between surface of adsorbents and metals ions and weak electrostatic interaction with surface. The adsorption capacities of all three adsorbents are increased with increasing of the concentration of adsorbents which proved that increase of more active sites on the surface. The removal adsorption of thiol-MNP is higher than carboxyl and amine. It can be explained on the basis of Pearson's hard soft acid base theory. The thiol is the soft Lewis base so that more interaction with soft Lewis acid such heavy metal ions. The removal efficiency decreases in the case of As(III) after increase in the $\mathrm{pH}$ because of $\mathrm{As}(\mathrm{III})$ hydrolyzed to $\mathrm{As}(\mathrm{OH})_{4}{ }^{-}$. The adsorption kinetic experiment was performed with amine-MNP which suggested that most of adsorption achieved within less than 15 minutes and pseudoequilibrium at $60 \mathrm{~min}$. The adsorption takes place in two stages, a very fast and other very slow. The desorption experiment was performed using $10 \mathrm{~mL}$ $0.1 \mathrm{M} \mathrm{HCl}$. All heavy metals were removed over to $85 \%$. The removal efficiency gradually decreases after repeating three times. About $80 \%$ recovery could be achieved after three recycles. Surface of $\mathrm{Fe}_{3} \mathrm{O}_{4}$ with carboxy methyl- $\beta$ cyclodextrin $(\mathrm{CM} \beta \mathrm{CD})$ base magnetic nanoadsorbent selectively removes heavy metals such as of $\mathrm{Pb}(\mathrm{II}), \mathrm{Cd}(\mathrm{II})$, and $\mathrm{Ni}(\mathrm{II})$. The adsorption capacity of $\mathrm{Pb}(\mathrm{II}), \mathrm{Cd}(\mathrm{II})$, and $\mathrm{Ni}(\mathrm{II})$, $64.5,27.7$, and $13.2 \mathrm{mg} / \mathrm{g}$, respectively [110]. Shellac is an natural biodegradable resin bearing hydroxyl and carboxyl group attached to $\mathrm{Fe}_{3} \mathrm{O}_{4}$ and demonstrated to remove $\mathrm{Cd}(\mathrm{II})$. The maximum adsorption capacity for removal of $\mathrm{Cd}(\mathrm{II})$ is $18.80 \mathrm{mg} / \mathrm{g}$ [111]. Superparamagnetic iron oxide nanaparticles surface was modified with dimercaptosuccinic acid (DMSA). They are demonstrated for removal of toxic metals such as a $\mathrm{Hg}, \mathrm{Ag}, \mathrm{Pb}, \mathrm{Cd}$, and $\mathrm{Tl}$. The ligand DMSA effectively binds to metals. DMSA- $\mathrm{Fe}_{3} \mathrm{O}_{4}$ exhibited a capacity $227 \mathrm{mg} / \mathrm{g}$ of mercury which is a 30 -fold larger value than conventional resin based sorbents (GT-73) [112]. The chemical affinity, capacity, kinetics, and stability of these adsorbents were compared with GT-73, activated carbon, and nonporous silica in ground water, river water, sea water, human blood, and plasma. The MNPs-DMSA were efficiently removed $99 \mathrm{wt} \%$ of $1 \mathrm{mg} / \mathrm{L} \mathrm{Pb}$ within a minute. However other adsorbents such as GT-73 and chelex-100 took 120 and 10 min times to remove $96 \%$ of $\mathrm{Pb} .1,6$-Hexanediamine immobilized on the surface of $\mathrm{Fe}_{3} \mathrm{O}_{4}$. They are able to remove $98 \%$ of $\mathrm{Pb}(\mathrm{II})$ from the industrial water and tap water. The maximum adsorption capacity of $\mathrm{Pb}(\mathrm{II})$ is $40.10 \mathrm{mg} / \mathrm{g}$ by MNPs- $\mathrm{NH}_{2}$ [113]. Magnetic nanoparticles were synthesized by three different methods such as coprecipitation, coprecipitation surface decoration, and polyol method [114]. The average particles sizes of all three methods are 8, 12, and $35 \mathrm{~nm}$. These three are the important adsorbents for the removal of heavy metals such $\mathrm{Ni}(\mathrm{II}), \mathrm{Cd}(\mathrm{II}), \mathrm{Cr}(\mathrm{II})$, and $\mathrm{Cu}(\mathrm{II})$ from the waste water. The maximum adsorption capacities to detoxify heavy metals are $5.15,7.45$, and $35.46 \mathrm{mg} / \mathrm{g}$, respectively. $\mathrm{Fe}_{3} \mathrm{O}_{4}$ $\mathrm{NH}_{2} /$ PEI-EDTA with an average diameter of $60 \mathrm{~nm}$ could be removed from multicomponent heavy metals such as $\mathrm{Cu}(\mathrm{II}), \mathrm{Cd}(\mathrm{II})$, and $\mathrm{Pb}(\mathrm{II})$. At $\mathrm{pH}$ near about $98 \% \mathrm{~Pb}(\mathrm{II})$ were 
removed from the aqueous mixture [115]. Poly2-aminoethyl methacrylate hydrochloride polymer chain on $\mathrm{Fe}_{3} \mathrm{O}_{4}$ was followed by the transformation of pendant amino groups into dithiocarbamate (DTC) groups. This polymer-brush-based DTC-functionalized magnetic nanoadsorbent exhibits high chelating affinity toward $\mathrm{Hg}(\mathrm{II})$ and is able to remove complete mercury from the water. The author has also compared the capacity and efficiency of this adsorbent for removal of $\mathrm{Hg}$ (II) with its monolayer analogue that was prepared from direct transformation of amino groups of 3-aminopropyl triethoxysilane (APTEs) functionalize $\mathrm{Fe}_{3} \mathrm{O}_{4}$ to DTC functional group and other parameters such as adsorption thermodynamic, kinetics, and Langmuir and Freundlich isotherm which were also evaluated. The high surface functional group on $\mathrm{Fe}_{3} \mathrm{O}_{4}$-polyAEMA-DTC make it high efficiency adsorbent as compared to their monolayer analogues [116]. A novel CD/MWCNT-iron oxide composite was prepared by plasma-induced technique. They showed the high magnetic property and good dispersity in layer and also increased the adsorption capacity to detoxify the $\mathrm{Zn}$ (II) [117]. Hierarchical $\mathrm{MnO}_{2}$-cated with magnetic nanocomposite $\left(\mathrm{Fe}_{3} \mathrm{O}_{4} / \mathrm{MnO}_{2}\right)$ was synthesized by hydrothermal process which showed the flower-like morphology. They are employed to remove heavy metal ions from the water. The high surface area and high magnetic saturation make them has good adsorption ability. The removal efficiency of $\mathrm{Fe}_{3} \mathrm{O}_{4} / \mathrm{MnO}_{2}$ was compared with unmodified $\mathrm{Fe}_{3} \mathrm{O}_{4}$ nanoparticles for heavy metals such $\mathrm{Cd}(\mathrm{II}), \mathrm{Cu}(\mathrm{II}), \mathrm{Pb}(\mathrm{II})$, and $\mathrm{Zn}(\mathrm{II})$. According to Langmuir equilibrium sorption model, maximum adsorption capacity of $\mathrm{Cd}(\mathrm{II})$ was $53.2 \mathrm{mg} / \mathrm{g} . \mathrm{Fe}_{3} \mathrm{O}_{4} / \mathrm{MnO}_{2}$ retained over $80 \%$ of its adsorption capacity under various solution conditions that are typically encountered in natural waters. In presence of external magnetic field it was easily recovered and reused through consecutive adsorptiondesorption experiments [118]. Near about $100 \%$ heavy metals were removed using $\mathrm{Fe}_{3} \mathrm{O}_{4}$-Zno magnetic semiconductor nanoparticles [119]. $\mathrm{MnFe}_{2} \mathrm{O}_{4} @ \mathrm{Mn}$-Co oxide based magnetic adsorbents have the maximum adsorption capacity to remove $\mathrm{Pb}(\mathrm{II}), \mathrm{Cu}(\mathrm{II})$, and $\mathrm{Cd}(\mathrm{II})$ were $481.2,386.2$, and $345.5 \mathrm{mg} / \mathrm{g}$, respectively [120]. Polyacrylic acid covalently supported on the surface of $\mathrm{Fe}_{3} \mathrm{O}_{4}$ which further functionalize with amine group using diethylenetriamine. They are demonstrated for removal of $\mathrm{Cu}(\mathrm{II})$ and $\mathrm{Cr}(\mathrm{VI})$. The Langmuir isotherms for maximum adsorption capacity for both are $12.43 \mathrm{mg} / \mathrm{g}$ and $11.24 \mathrm{mg} / \mathrm{g}$, respectively [121]. IONPs prepared by co-precipitation method followed by modification with 3-aminopropyltriethoxy silane and acrylic chloride which further grafted with polyacrylic acid. It is useful to removal of heavy metal such as $\mathrm{Cd}(\mathrm{II}), \mathrm{Pb}(\mathrm{II}), \mathrm{Ni}(\mathrm{II})$, and $\mathrm{Cu}(\mathrm{II})$ [122]. Magnetite nanorods with average diameter $60 \mathrm{~nm}$ were prepared by pulsed current electrochemical method. The implication of this nanorod for removal of heavy metals such as $\mathrm{Fe}(\mathrm{II}), \mathrm{Zn}(\mathrm{II}), \mathrm{Cu}(\mathrm{II}), \mathrm{Pb}(\mathrm{II}), \mathrm{Ni}(\mathrm{II})$, and $\mathrm{Cd}$. The Langmuir maximum adsorptions of these metals are 127, 107.27, 79.10, $112.86,95.42$, and $88.38 \mathrm{mg} / \mathrm{g}$, respectively [123].

\section{Silica Based Magnetic Adsorbent for Removal of Heavy Metals}

Silica coated magnetic nanoadsorbents provide stability and increase adsorption efficiency. Silica-modified magnetite NPs functionalized with cetylpyridinium bromide complexation with 8-hydroxy quinoline used for detection of heavy metal ions such as $\mathrm{Cd}(\mathrm{II}), \mathrm{Co}(\mathrm{II}), \mathrm{Cu}(\mathrm{II}), \mathrm{Mn}(\mathrm{II}), \mathrm{Ni}(\mathrm{II})$, and $\mathrm{Pb}(\mathrm{II})$ from the water samples; however, detection limit of $\mathrm{Cd}(\mathrm{II})$, $\mathrm{Co}(\mathrm{II}), \mathrm{Cu}(\mathrm{II}), \mathrm{Mn}(\mathrm{II}), \mathrm{Ni}(\mathrm{II})$, and $\mathrm{Pb}$ (II) are 2.3, 9.5, 4.7, 15.3, 9.1, and 7.4, respectively in $\mathrm{ng} / \mathrm{L}$ [124]. The porous magnetic spheres are prepared using Stöber and hydrothermal process and useful nanoadsorbent for detoxification of $\mathrm{Ni}$ (II) [125]. Wang et al. reported a novel amino functionalized $\mathrm{Fe}_{3} \mathrm{O}_{4} @ \mathrm{SiO}_{2}$ prepared by co-precipitation method [126] and characterized by XRD, VSM, TGA, zeta potential, and XPS. Amine functional group introduced by using silylation reagent 3-aminopropyltromethoxy silane. The BET surface area of $\mathrm{Fe}_{3} \mathrm{O}_{4}, \mathrm{Fe}_{3} \mathrm{O}_{4} @ \mathrm{SiO}_{2}$, and $\mathrm{Fe}_{3} \mathrm{O}_{4} @ \mathrm{SiO}_{2}$ $\mathrm{NH}_{2}$ is $114,318.5$, and 216.2, respectively. The absorption peak at $565 \mathrm{~cm}^{-1}$ of $\mathrm{Fe}-\mathrm{O}$ vibration. The adsorption bands at $1220,1094,804$, and $471 \mathrm{~cm}^{-1}$ are the starching and deformation vibration of $\mathrm{SiO}_{2}$ which indicate coating of $\mathrm{SiO}_{2}$ on magnetic nanoparticles. It was further confirmed by others that observed absorption bands are 3361, 1572, 1498, and $692 \mathrm{~cm}^{-1}$ of stretching and bending vibration of amino group. XRD pattern at $30.4^{\circ}, 35.6^{\circ}, 43.3^{\circ}, 57.3^{\circ}$, and $62.8^{\circ}$ resulted in cubic spinel structure of $\mathrm{Fe}_{3} \mathrm{O}_{4}$ as well as same pattern also observed for $\mathrm{Fe}_{3} \mathrm{O}_{4} @ \mathrm{SiO}_{2}$ and $\mathrm{Fe}_{3} \mathrm{O}_{4} @ \mathrm{SiO}_{2}-$ $\mathrm{NH}_{2}$ showed stability of magnetic particles after coating $\mathrm{SiO}_{2}$ layer. The particles size of $\mathrm{Fe}_{3} \mathrm{O}_{4}, \mathrm{Fe}_{3} \mathrm{O}_{4} @ \mathrm{SiO}_{2}$, and $\mathrm{Fe}_{3} \mathrm{O}_{4} @ \mathrm{SiO}_{2}-\mathrm{NH}_{2}$ were 12.1, 13, and $13.4 \mathrm{~nm}$ calculated by using Scherrer equation respectively. The TEM image of three nanoparticles displayed core-shell structure with average particle sizes are $13.4,16.6$, and $18.4 \mathrm{~nm}$, respectively. The saturation magnetization for $\mathrm{Fe}_{3} \mathrm{O}_{4}, \mathrm{Fe}_{3} \mathrm{O}_{4} @ \mathrm{SiO}_{2}$ and $\mathrm{Fe}_{3} \mathrm{O}_{4} @ \mathrm{SiO}_{2}-\mathrm{NH}_{2} 68,36.2$ and $34 \mathrm{emu} / \mathrm{g}$, respectively, which indicate that all three nanaparticles are in superparamagnetic. Surface composition was measured by XPS in which result showed that $\mathrm{Fe}_{2 \mathrm{p} 3 / 2}, \mathrm{Si}_{2 \mathrm{p} 2}$, and $\mathrm{N}_{1 \mathrm{~s}}$ are 2.73, 20.37 and 3.23 for $\mathrm{Fe}_{3} \mathrm{O}_{4} @ \mathrm{SiO}_{2}-\mathrm{NH}_{2}$. The zeta potential was performed to measure surface charge. The values of zeta potential of $\mathrm{Fe}_{3} \mathrm{O}_{4} @ \mathrm{SiO}_{2}$ and $\mathrm{Fe}_{3} \mathrm{O}_{4} @ \mathrm{SiO}_{2}-\mathrm{NH}_{2}$ were increased that indicated the stability of nanaparticles. The isoelectric point (IEP) of $\mathrm{Fe}_{3} \mathrm{O}_{4} @ \mathrm{SiO}_{2}$ and $\mathrm{Fe}_{3} \mathrm{O}_{4} @ \mathrm{SiO}_{2}-\mathrm{NH}_{2}$ is 1.4 and 6 which showed the successful coating of silica layer and amine group on magnetite nanoparticles. The adsorption obeyed Langmuir isotherm equation. The adsorption capacities to remove heavy metals such as $\mathrm{Cu}(\mathrm{II}), \mathrm{Pb}(\mathrm{II})$, and $\mathrm{Cd}(\mathrm{II})$ at $25^{\circ} \mathrm{C}$ are $0.47,0.37$, and $0.20 \mathrm{mmol} / \mathrm{g}$, respectively. The adsorption capacity increased with increasing temperature indicating endothermic nature of adsorption process. There is no drastic change on the adsorption of $\mathrm{Cu}$ (II) in the presence of humic acid but slightly decreased in adsorption capacity of $\mathrm{Cu}(\mathrm{II})$ in the presence of $\mathrm{Na}, \mathrm{K}$, and $\mathrm{Mg}$ because of competitive binding of these metals to adsorbent surface. $\mathrm{Fe}_{3} \mathrm{O}_{4} @ \mathrm{SiO}_{2}-\mathrm{NH}_{2}$ exhibited good adsorption capacity after regeneration in the presence of acid. $\mathrm{Fe}_{3} \mathrm{O}_{4} @ \mathrm{SiO}_{2}$ prepared by using silica source $\mathrm{Na}_{2} \mathrm{SiO}_{3}$ and then modified with thiol group [127]. These showed high adsorption efficiency. They are able to remove $148.8 \mathrm{mg} / \mathrm{g}$ of mercury at pH 6.5 calculated from Langmuir isotherm equation. After recycling they showed $110 \mathrm{mg} / \mathrm{g}$ adsorption 
TABle 4: Pore diameter, pore volume, BET surface area, and adsorption capacity of SH-mSi@ $\mathrm{Fe}_{3} \mathrm{O}_{4}$.

\begin{tabular}{lccc}
\hline & & & Adsorption capacity (mg/g) \\
Pore volume $\left(\mathrm{cm}^{3} / \mathrm{g}\right)$ & Pore diameter $(\mathrm{nm})$ & Surface area BET $\left(\mathrm{m}^{2} / \mathrm{g}\right)$ & \multicolumn{2}{c}{$\begin{array}{c}\text { Pb } \\
\mathrm{Pb}\end{array}$} & 321.5 \\
\hline 0.29 & 2.5 & 321 & 91.5 \\
\hline
\end{tabular}

capacity. Mesoporous silica nanoparticles based material such as MCM-41, MCM-48, and SBA-15 are one of the most important advanced materials. They have important features such as high surface area, definite pore size, and pore volume that make them ideal candidates for the remediation of water. Functionalization of such materials improved their physical and chemical properties and enhanced their adsorption capacity particularly for removal of pollutants. Multifunction microspheres with large pore sized mesoporous silica nanoparticles that contain $\mathrm{Fe}_{3} \mathrm{O}_{4}$ have been synthesized by sol-gel method using CTAB as surfactant [128]. They also modified amine functional group with using APTMS. Here CTAB first dissolved in water which resulted in $\mathrm{Fe}_{3} \mathrm{O}_{4} @ \mathrm{SiO}_{2} @$ meso- $\mathrm{SiO}_{2}-\mathrm{R}_{1}$ while CTAB added directly to $\mathrm{Fe}_{3} \mathrm{O}_{4} @ \mathrm{SiO}_{2}$ called $\mathrm{Fe}_{3} \mathrm{O}_{4} @ \mathrm{SiO}_{2} @$ meso$\mathrm{SiO}_{2}-\mathrm{R}_{2}$. The surface area, pore volume, and pore size of $\mathrm{Fe}_{3} \mathrm{O}_{4} @ \mathrm{SiO}_{2} @$ meso- $\mathrm{SiO}_{2}-\mathrm{R}_{1}$ bearing amine functional group are $365\left(\mathrm{~m}^{2} / \mathrm{g}\right), 0.51\left(\mathrm{~cm}^{3} / \mathrm{g}\right)$, and $9.9(\mathrm{~nm})$, respectively. However $\mathrm{Fe}_{3} \mathrm{O}_{4} @ \mathrm{SiO}_{2} @ \mathrm{meso}_{-} \mathrm{SiO}_{2}-\mathrm{R}_{2}$ contains amine functional group has surface area, pore volume, and pore size of $474\left(\mathrm{~m}^{2} / \mathrm{g}\right), 0.64\left(\mathrm{~cm}^{3} / \mathrm{g}\right)$, and $2.1(\mathrm{~nm})$, respectively. The maximum adsorption capacity of $\mathrm{Fe}_{3} \mathrm{O}_{4} @ \mathrm{SiO}_{2} @$ meso- $\mathrm{SiO}_{2}-$ $\mathrm{R}_{1}-\mathrm{NH}_{2}$ to remove $\mathrm{Pb}(\mathrm{II}), \mathrm{Cd}(\mathrm{II})$, and $\mathrm{Cu}(\mathrm{II})$ is $880,492.4$, and $628.3 \mathrm{mg} / \mathrm{g} . \mathrm{Fe}_{3} \mathrm{O}_{4} @ \mathrm{SiO}_{2} @$ meso- $\mathrm{SiO}_{2}-\mathrm{R}_{2}-\mathrm{NH}_{2}$ show maximum adsorption capacity, 289.7, 154.2, and $196.5 \mathrm{mg} / \mathrm{g}$ for $\mathrm{Pb}(\mathrm{II}), \mathrm{Cd}(\mathrm{II})$, and $\mathrm{Cu}(\mathrm{II}) . \mathrm{Fe}_{3} \mathrm{O}_{4} @ \mathrm{SiO}_{2} @$ meso$\mathrm{SiO}_{2}-\mathrm{R}_{1}-\mathrm{NH}_{2}$ showed higher adsorption capacity than $\mathrm{Fe}_{3} \mathrm{O}_{4} @ \mathrm{SiO}_{2} @ m e s o-\mathrm{SiO}_{2}-\mathrm{R}_{2}-\mathrm{NH}_{2}$ due to more amine group grated to $\mathrm{Fe}_{3} \mathrm{O}_{4} @ \mathrm{SiO}_{2} @ m e s o-\mathrm{SiO}_{2}-\mathrm{R}_{1}-\mathrm{NH}_{2}$ and other explanation parameter of maximum adsorption mechanism are Langmuir and Freundlich isotherm equation. Basis on value of correlation coefficients $\left(R^{2}\right)$ fitted in Langmuir isotherm equation for $\mathrm{Pb}(\mathrm{II}), \mathrm{Cu}(\mathrm{II})$, and $\mathrm{Cd}(\mathrm{II})$ is 0.990 , 0.996, and 0.990, respectively; however according to Freundlich isotherm equation correlation coefficients $\left(R^{2}\right)$ value for $\mathrm{Pb}(\mathrm{II}), \mathrm{Cu}(\mathrm{II})$, and $\mathrm{Cd}(\mathrm{II})$ are $0.898,0.922$, and 0.940 , respectively. The Langmuir experimental data are most suitable and proved that those active sites are distributed in homogeneous fashion to $\mathrm{Fe}_{3} \mathrm{O}_{4} @ \mathrm{SiO}_{2} @ m e s o-$ $\mathrm{SiO}_{2}-\mathrm{R}_{1}-\mathrm{NH}_{2}$ microspheres that showed good adsorption capacity after recycling five times. Thiol functionalized magnetic mesoporous silica nanoparticles are prepared and demonstrated for the heavy metals such as $\mathrm{Hg}$ and $\mathrm{Pb}$ [129]. The pore diameter, BET surface area, and pore volume and maximum adsorption capacity as fitted with Langmuir isotherm are summarized in Table 4. The removal efficiency and effect of $\mathrm{pH}$ have also been investigated. The binding efficiency with meso- $\mathrm{SiO}_{2} @ \mathrm{Fe}_{3} \mathrm{O}_{4}-\mathrm{SH}$ is $\mathrm{Ag}(\mathrm{I}) \approx$ $\mathrm{Hg}(\mathrm{II})>\mathrm{Pb}(\mathrm{II})>\mathrm{Cu}(\mathrm{II})$. The increase in $\mathrm{pH}$ enhanced the adsorption capacity also. They were employed for the removal of heavy metals from the natural water resources. The removal efficiency of heavy metals such as $\mathrm{Pb}, \mathrm{Ag}$, and $\mathrm{Hg}$ is more than $95 \%$ while for copper not more than $80 \%$. Low efficiency of copper is due to weak bind to thiol group. It is stable in various natural water in extreme acidic and basic condition. The saturation magnetization of $\mathrm{SiO}_{2} @ \mathrm{Fe}_{3} \mathrm{O}_{4}-\mathrm{SH}$ is $38.4 \mathrm{emu} / \mathrm{g}$. The super paramagnetism nature of help to remove adsorbent in the presence of external magnetic field. The removal efficiency was tested with $\mathrm{Hg}$ (II). The result showed that more than $90 \%$ of $\mathrm{Hg}(\mathrm{II})$ is removed after repeated six times magnetic $\gamma-\mathrm{Fe}_{2} \mathrm{O}_{3}$ nanoparticles embedded on the ordered mesoporous carbon (CMK-3) with high surface area which is applicable as magnetic adsorbent to remove toxic chromium(VI) [130].

\section{Conclusion}

Application of iron oxide nanoparticles based novel magnetic materials for removal of heavy metals from the aqueous systems developed as high efficient and cost-effective nanoadsorbent. Surface modification approach enhanced their stability and efficiency in the water. Magnetic nanoparticles possess an important magnetic property which helps to remove easily in the presence of magnetic field. The reuse of magnetic nanoadsorbent will decrease economic burden. Magnetic nanoadsorbent technology for water remediation is the more convenient and appropriate for removing and separating heavy metals. Before their bulk application health effect and fate into environment of magnetic base nanomaterial should be addressed.

\section{Abbreviations}

AF: $\quad$ Amine functionalize

AEMA: Aminoethyl methacrylate

APS: 3-Aminopropyltriethoxy silane

APTMS: Aminotrimethoxysilane

ATRP: Atom transfer radical polymerization

CNTs: $\quad$ Carbon nanotubes

CM $\beta$ CD: Carboxymethyl- $\beta$-cyclodextrin

CTAB: Cetrimethyl ammonium bromide

CS: Chitosan

CCMNPs: Chitosan-coated magnetic nanoparticles

DMSA: Dimercaptosuc cinicacid

DTC: dithiocarbamate,

EDA: ethylenediamine,

EDTA: Ethylenediaminetetraacetic

FA: $\quad$ Foli acid 
GMA: Glycidyl methyl acrylate

GA: $\quad$ Gum arabic

HA: Humic acid

INOPs: Iron oxide nanaparticles

KA: $\quad$ Ketoglutaric acid

MNP: Magnetic nanoparticle

MNPs: Magnetic nanaparticles

MBT: 2-Mercaptobenzothiazole

MSA: Mercaptosuccinic

NHS: N-Hydroxy succinimide

PAA: Polyacrylic acid

PCL: Polycaprolactone

PEG: Polyethylene glycol

PEGMA: Polyethylene glycol methacrylate

PEI: $\quad$ Polyethylenimine

PMA: Polymethacrylate

PPy: Polypyrrol

SA: $\quad$ Succinic acid

SPI-NOs: Super paramagnetic iron oxides nanoparticles

USEPA: United States Environment Protection Agency.

\section{Conflict of Interests}

The authors declare that there is no conflict of interests regarding the publication of this paper.

\section{References}

[1] R. P. Schwarzenbach, T. Egli, T. B. Hofstetter, U. Von Gunten, and B. Wehrli, "Global water pollution and human health," Annual Review of Environment and Resources, vol. 35, pp. 109136, 2010.

[2] M. Fujita, Y. lde, D. Sato et al., "Heavy metal contamination of coastal lagoon sediments: fongafale islet, Funafuti atoll, tuvalu," Chemosphere, vol. 95, pp. 628-634, 2014.

[3] S. K. Al-Musharsfi, I. Y. Mahmoud, and S. N. Al-Bahry, "Heavy metal pollution from treated sewage effluent," APCBEE Procedia, vol. 5, pp. 344-348, 2013.

[4] H. A. Naser, "Assessment and management of heavy metal pollution in the marine environment of the Arabian Gulf, a review," Marine Pollution Bulletin, vol. 72, no. 1, pp. 6-13, 2013.

[5] G. Akinci, D. E. Guven, and S. K. Ugurlu, "Assessing pollution in Izmir Bay from rivers in western Turkey: heavy metals," Environmental Science, vol. 15, no. 12, pp. 2252-2262, 2013.

[6] F. Zan, S. Huo, B. Xi et al., "A 100 year sedimentary record of heavy metal pollution in a shallow eutrophic lake, Lake Chaohu, China," Journal of Environmental Monitoring, vol. 13, no. 10, pp. 2788-2797, 2011.

[7] S.-L. Wang, X.-R. Xu, Y.-X. Sun, J.-L. Liu, and H.-B. Li, "Heavy metal pollution in coastal of South China: a review," Marine Pollution Bulletin, vol. 76, no. 1-2, pp. 7-15, 2013.

[8] Z. Li, Z. Ma, T. J. D. Kuijp, Z. Yuan, and L. Huang, "A review of soil heavy metal pollution from mines in China: pollution and health risk assessment," Science of The Total Environment, vol. 468-469, pp. 843-853, 2014.

[9] S. S. Gowd, M. R. Reddy, and P. K. Govil, "Assessment of heavy metal contamination in soils at Jajmau (Kanpur) and Unnao industrial areas of the Ganga Plain, Uttar Pradesh, India,"
Journal of Hazardous Materials, vol. 174, no. 1-3, pp. 113-121, 2010.

[10] P. C. Deshpande, A. K. Tilwankar, and S. R. Asolekar, "A novel approach to estimating potential maximum exposure to ship recycling yard workers in Alang," Science of the Total Environment, vol. 438, pp. 304-311, 2012.

[11] F. Fu and Q. Wang, "Removal of heavy metal ions from wastewaters: a review," Journal of Environmental Management, vol. 92, no. 3, pp. 407-418, 2011.

[12] M. A. Hashim, S. Mukhopadhyay, J. N. Sahu, and B. Sengupta, "Remediation technologies for heavy metal contaminated groundwater," Journal of Environmental Management, vol. 92, no. 10, pp. 2355-2388, 2011.

[13] L. Zhang and M. Fang, "Nanomaterials in pollution trace detection and environmental improvement," Nano Today, vol. 5, no. 2, pp. 128-142, 2010.

[14] M. Hua, S. Zhang, B. Pan, W. Zhang, L. Lv, and Q. Zhang, "Heavy metal removal from water/wastewater by nanosized metal oxides: a review," Journal of Hazardous Materials, vol. 211212, pp. 317-331, 2012.

[15] B. I. Kharisov, H. V. R. Dias, O. V. Kharissova, V. M. JiménezPérez, B. O. Pérez, and B. M. Flores, "Iron-contain nanomaterial: synthesis, properties, and environmental applications," RSC Advances, vol. 2, no. 25, pp. 9325-9358.

[16] Z. Feng, S. Zhu, D. R. M. De Godoi, A. C. S. Samia, and D. Scherson, "Adsorption of $\mathrm{Cd}^{2+}$ on carboxyl-terminated superparamagnetic iron oxide nanoparticles," Analytical Chemistry, vol. 84, no. 8, pp. 3764-3770, 2012.

[17] P. Xu, G. M. Zeng, D. L. Huang et al., "Use of iron oxide nanomaterials in wastewater treatment: a review," Science of the Total Environment, vol. 424, pp. 1-10, 2012.

[18] C. L. Warner, W. Chouyyok, K. E. Mackie et al., "Manganese doping of magnetic iron oxide nanoparticles: tailoring surface reactivity for a regenerable heavy metal sorbent," Langmuir, vol. 28, no. 8, pp. 3931-3937, 2012.

[19] A. E. Karatapanis, D. E. Petrakis, and C. D. Stalikas, "A layered magnetic iron/iron oxide nanoscavenger for the analytical enrichment of ng-L-1 concentration levels of heavy metals from water," Analytica Chimica Acta, vol. 726, pp. 22-27, 2012.

[20] H. Yang, Z. Tian, J. Wang, and S. Yang, "A magnetic resonance imaging nanosensor for $\mathrm{Hg}$ (II) based on thymidinefunctionalized supermagnetic iron oxide nanoparticles," Sensors and Actuators B, vol. 161, no. 1, pp. 429-433, 2012.

[21] A. S. Teja and P.-Y. Koh, "Synthesis, properties, and applications of magnetic iron oxide nanoparticles," Progress in Crystal Growth and Characterization of Materials, vol. 55, no. 1-2, pp. 22-45, 2009.

[22] Z. Liu, H. Wang, C. Liu et al., "Magnetic cellulose-chitosan hydrogels prepared from ionic liquids as reusable adsorbent for removal of heavy metal ions," Chemical Communications, vol. 48, no. 59, pp. 7350-7352, 2012.

[23] J. K. Oh and J. M. Park, "Iron oxide-based superparamagnetic polymeric nanomaterials: design, preparation, and biomedical application," Progress in Polymer Science, vol. 36, no. 1, pp. 168189, 2011.

[24] S. Laurent, D. Forge, M. Port et al., "Magnetic iron oxide nanoparticles: synthesis, stabilization, vectorization, physicochemical characterizations and biological applications," Chemical Reviews, vol. 108, no. 6, pp. 2064-2110, 2008.

[25] L. H. Reddy, J. L. Arias, J. Nicolas, and P. Couvreur, "Magnetic nanoparticles: design and characterization, toxicity and 
biocompatibility,pharmaceutical and biomedical applications," Chemical Reviews, vol. 112, no. 11, pp. 5818-5878, 2012.

[26] M. Mahmoudi, S. Sant, B. Wang, S. Laurent, and T. Sen, "Superparamagnetic iron oxide nanoparticles (SPIONs): development, surface modification and applications in chemotherapy," Advanced Drug Delivery Reviews, vol. 63, no. 1-2, pp. 2446, 2011.

[27] K. Petcharoen and A. Sirivat, "Synthesis and characterization of magnetite nanoparticles via the chemical co-precipitation method," Materials Science and Engineering B, vol. 177, no. 5, pp. 421-427, 2012.

[28] T. Hyeon, S. S. Lee, J. Park, Y. Chung, and B. N. Hyon, "Synthesis of highly crystalline and monodisperse maghemite nanocrystallites without a size-selection process," Journal of the American Chemical Society, vol. 123, no. 51, pp. 12798-12801, 2001.

[29] S. Belaid, S. Laurent, M. Vermeersch, L. V. Elst, D. P. Morga, and R. N. Muller, "A new approach to follow the formation of iron oxide nanoparticles synthesized by thermal decomposition," Nanotechnology, vol. 24, no. 5.

[30] Y.-H. Zheng, Y. Cheng, F. Bao, and Y.-S. Wang, "Synthesis and magnetic properties of $\mathrm{Fe}_{3} \mathrm{O}_{4}$ nanoparticles," Materials Research Bulletin, vol. 41, no. 3, pp. 525-529, 2006.

[31] B. Behdadfar, A. Kermanpur, H. Sadeghi-Aliabadi, M. D. P. Morales, and M. Mozaffari, "Synthesis of high intrinsic loss power aqueous ferrofluids of iron oxide nanoparticles by citric acid-assisted hydrothermal-reduction route," Journal of Solid State Chemistry, vol. 187, pp. 20-26, 2012.

[32] H. Cai, X. An, J. Cui et al., "Facile hydrothermal synthesis and surface functionalization of polyethyleneimine-coated iron oxide nanoparticlesfor biomedical applications," ACS Applied Materials \& Interfaces, vol. 5, no. 5, pp. 1722-1731, 2013.

[33] S. Cui, X. Shen, and B. Lin, "Surface organic modification of $\mathrm{Fe}_{3} \mathrm{O}_{4}$ nanoparticles by silane-coupling agents," Rare Metals, vol. 25, no. 6, pp. 426-430, 2006.

[34] H. Mohammad-Beigi, S. Yaghmaei, R. Roostaazad, H. Bardania, and A. Arpanaei, "Effect of $\mathrm{pH}$, citrate treatment and silanecoupling agent concentration on the magnetic, structural and surface properties of functionalized silica-coated iron oxide nanocomposite particles," Physica E, vol. 44, no. 3, pp. 618-627, 2011.

[35] S. Kango, S. Kalia, A. Celli, J. Njuguna, Y. Habibi, and R. Kumar, "Surface modification of inorganic nanoparticles for development of organic-inorganic nanocomposites," Progress in Polymer Science, vol. 38, no. 8, pp. 1232-1261, 20.

[36] C. Barrera, A. P. Herrera, N. Bezares et al., "Effect of poly(ethylene oxide)-silane graft molecular weight on the colloidal properties of iron oxide nanoparticles for biomedical applications," Journal of Colloid and Interface Science, vol. 377, no. 1, pp. 40-50, 2012.

[37] E. K. U. Larsen, T. Nielsen, T. Wittenborn et al., "Size-dependent accumulation of pegylated silane-coated magnetic iron oxide nanoparticles in murine tumors," ACS Nano, vol. 3, no. 7, pp. 1947-1951, 2009.

[38] F. . Ahangaran, A. Hassanzadeh, and S. Nouril, "Surface modification of $\mathrm{Fe}_{3} \mathrm{O}_{4} @ \mathrm{SiO}_{2}$ microsphere by silane coupling agent," International Nano Letters, vol. 233, no. 23, pp. 1-5.

[39] D. Forge, S. Laurent, Y. Gossuin, A. Roch, L. Vander Elst, and R. N. Muller, "An original route to stabilize and functionalize magnetite nanoparticles for theranosis applications," Journal of Magnetism and Magnetic Materials, vol. 323, no. 5, pp. 410-415, 2011.
[40] J. I. Cutler, D. Zheng, X. Xu, D. A. Giljohann, and C. A. Mirkin, "Polyvalent oligonucleotide iron oxide nanoparticle "click" conjugates," Nano Letters, vol. 10, no. 4, pp. 1477-1480, 2010.

[41] C. Huang, K. G. Neoh, and E.-T. Kang, "Combined ATRP and 'click' chemistry for designing stable tumor-targeting superparamagnetic iron oxide nanoparticles," Langmuir, vol. 28, no. 1, pp. 563-571, 2012.

[42] C. Huang, K. G. Neoh, and E.-T. Kang, "Combined ATRP and 'click' chemistry for designing stable tumor-targeting superparamagnetic iron oxide nanoparticles," Langmuir, vol. 28, no. 1, pp. 563-571, 2012.

[43] C. Huang, K. G. Neoh, L. Xu, E. T. Kang, and E. Chiong, "Polymeric nanoparticles with encapsulated superparamagnetic iron oxide and conjugated cisplatin for potential bladder cancer therapy," Biomacromolecules, vol. 13, no. 8, pp. 2513-2520, 2012.

[44] L. Wang, K. G. Neoh, E. T. kang, and B. Shuter, "Methotrexateconjugated and hyperbranched polyglycerol-grafted $\mathrm{Fe}_{3} \mathrm{O}_{4}$ magnetic nanoparticles for targeted anticancer effects," European Journal of Pharmaceutical Sciences, vol. 48, no. 1-2, pp. 111120, 2013.

[45] J. Vidal-Vidal, J. Rivas, and M. A. López-Quintela, "Synthesis of monodisperse maghemite nanoparticles by the microemulsion method," Colloids and Surfaces A, vol. 288, no. 1-3, pp. 44-51, 2006.

[46] A. B. Chin and I. I. Yaacob, "Synthesis and characterization of magnetic iron oxide nanoparticles via w/o microemulsion and Massart's procedure," Journal of Materials Processing Technology, vol. 191, no. 1-3, pp. 235-237, 2007.

[47] L.-H. Han, H. Liu, and Y. Wei, "In situ synthesis of hematite nanoparticles using a low-temperature microemulsion method," Powder Technology, vol. 207, no. 1-3, pp. 42-46, 2011.

[48] R. J. Joseyphus, D. Kodama, T. Matsumoto, Y. Sato, B. Jeyadevan, and K. Tohji, "Role of polyol in the synthesis of Fe particles," Journal of Magnetism and Magnetic Materials, vol. 310, no. 2, pp. 2393-2395, 2007.

[49] W. Cai and J. Wan, "Facile synthesis of superparamagnetic magnetite nanoparticles in liquid polyols," Journal of Colloid and Interface Science, vol. 305, no. 2, pp. 366-370, 2007.

[50] M. Abbas, B. P. Rao, S. M. Naga, M. Takahashi, and C. G. Kim, "Synthesis of high magnetization hydrophilic magnetite $\left(\mathrm{Fe}_{3} \mathrm{O}_{4}\right)$ nanoparticles in single reaction-surfactntless polyol process," Ceramics International, vol. 39, no. 7, pp. 7605-7611, 2013.

[51] R. Abu Mukh-Qasem and A. Gedanken, "Sonochemical synthesis of stable hydrosol of $\mathrm{Fe}_{3} \mathrm{O}_{4}$ nanoparticles," Journal of Colloid and Interface Science, vol. 284, no. 2, pp. 489-494, 2005.

[52] S.-J. Park, S. Kim, S. Lee, Z. G. Khim, K. Char, and T. Hyeon, "Synthesis and magnetic studies of uniform iron nanorods and nanospheres," Journal of the American Chemical Society, vol. 122, no. 35, pp. 8581-8582, 2000.

[53] E. H. Kim, H. S. Lee, B. K. Kwak, and B.-K. Kim, "Synthesis of ferrofluid with magnetic nanoparticles by sonochemical method for MRI contrast agent," Journal of Magnetism and Magnetic Materials, vol. 289, pp. 328-330, 2005.

[54] B. M. Kumfer, K. Shinoda, B. Jeyadevan, and I. M. Kennedy, "Gas-phase flame synthesis and properties of magnetic iron oxide nanoparticles with reduced oxidation state," Journal of Aerosol Science, vol. 41, no. 3, pp. 257-265, 2010.

[55] Y. Li, Y. Hu, G. Huang, and C. Li, "Metallic iron nanoparticles: flame synthesis, characterization and magnetic properties," Particuology, vol. 11, no. 4, pp. 460-467, 2013. 
[56] R. W. Saunders and J. M. C. Plane, "The formation and growth of $\mathrm{Fe}_{2} \mathrm{O}_{3}$ nanoparticles from the photo-oxidation of iron pentacarbonyl," Journal of Aerosol Science, vol. 41, no. 5, pp. 475489,2010

[57] H. Cui, Y. Liu, and W. Ren, "Structure switch between $\alpha$ $\mathrm{Fe}_{2} \mathrm{O}_{3}, \gamma-\mathrm{Fe}_{2} \mathrm{O}_{3}$ and $\mathrm{Fe}_{3} \mathrm{O}_{4}$ during the large scale and low temperature sol-gel synthesis of nearly monodispersed iron oxide nanoparticles," Advanced Powder Technology, vol. 24, no. 1, pp. 93-97, 2013.

[58] R. F. C. Marques, C. Garcia, P. Lecante et al., "Electroprecipitation of $\mathrm{Fe}_{3} \mathrm{O}_{4}$ nanoparticles in ethanol," Journal of Magnetism and Magnetic Materials, vol. 320, no. 19, pp. 23112315, 2008.

[59] L. Cabrera, S. Gutierrez, N. Menendez, M. P. Morales, and P. Herrasti, "Magnetite nanoparticles: electrochemical synthesis and characterization," Electrochimica Acta, vol. 53, no. 8, pp. 3436-3441, 2008.

[60] F. Fajaroh, H. Setyawan, W. Widiyastuti, and S. Winardi, "Synthesis of magnetite nanoparticles by surfactant-free electrochemical method in an aqueous system," Advanced Powder Technology, vol. 23, no. 3, pp. 328-333, 2012.

[61] S. Lin, D. Lu, and Z. Lu, "Removal of arsenic contaminants with magnetic $\gamma$ - $\mathrm{Fe}_{2} \mathrm{O}_{3}$ nanoparticles," Chemical Engineering, vol. 211-212, pp. 46-52, 2012.

[62] S. Luther, N. Borgfeld, J. Kim, and J. G. Parsons, "Removal of arsenic from aqueous solution: a study of the effects of $\mathrm{pH}$ and interfering ions using iron oxide nanomaterials," Microchemical Journal, vol. 101, pp. 30-36, 2012.

[63] W. Tang, Q. Li, S. Gao, and J. K. Shang, "Arsenic (III,V) removal from aqueous solution by ultrafine $\alpha-\mathrm{Fe}_{2} \mathrm{O}_{3}$ nanoparticles synthesized from solvent thermal method," Journal of Hazardous Materials, vol. 192, no. 1, pp. 131-138, 2011.

[64] M. Kilianova, R. Prucek, J. Filip et al., "Remarkable efficiency of ultrafine superparamagnetic iron (III) oxide nanoparticles toward arsenate removal from aqueous environment," Chemosphere, vol. 93, no. 11, pp. 2690-2697, 2013.

[65] K. Song, W. Kim, C.-Y. Suh, D. Shin, K.-S. Ko, and K. Ha, "Magnetic iron oxide nanoparticles prepared by electrical wire explosion for arsenic removal," Powder Technology, vol. 246, pp. 572-574, 2013.

[66] M. Kokate, K. Garadkar, and A. Gole, "One pot synthesis of magnetite -silica nanocomposites: applications as tags, entrapment matrix and in water purification," Journal of Materials Chemistry A, vol. 1, no. 6, pp. 2022-2029, 2013.

[67] S. Zhang, H. Niu, Y. Cai, X. Zhao, and Y. Shi, "Arsenite and arsenate adsorption on coprecipitated bimetal oxide magnetic nanomaterials: $\mathrm{MnFe}_{2} \mathrm{O}_{4}$ and $\mathrm{CoFe}_{2} \mathrm{O}_{4}$," Chemical Engineering Journal, vol. 158, no. 3, pp. 599-607, 2010.

[68] V. Chandra, J. Park, Y. Chun, J. W. Lee, I.-C. Hwang, and K. S. Kim, "Water-dispersible magnetite-reduced graphene oxide composites for arsenic removal," ACS Nano, vol. 4, no. 7, pp. 3979-3986, 2010.

[69] I. F. Nata, M. Sureshkumar, and C.-K. Lee, “One-pot preparation of amine-rich magnetite/bacterial cellulose nanocomposite and its application for arsenate removal," RSC Advances, vol. 1, no. 4, pp. 625-631, 2011.

[70] Z. Wu, W. Li, P. A. Webley, and D. Zhao, "General and controllable synthesis of novel mesoporous magnetic iron oxide@carbon encapsulates for efficient arsenic removal," Advanced Materials, vol. 24, no. 4, pp. 485-491, 2012.

[71] R. M. Dhoble, S. Lunge, A. G. Bhole, and S. Rayalu, "Magnetic binary oxide particles (MBOP): a promising adsorbent for removal of As (III) in water," Water Research, vol. 45, no. 16, pp. 4769-4781, 2011.

[72] Y. Tian, M. Wu, X. Lin, P. Huang, and Y. Huang, "Synthesis of magnetic wheat straw for arsenic adsorption," Journal of Hazardous Materials, vol. 193, pp. 10-16, 2011.

[73] J. Ma, Z. Zhu, B. Chen et al., "One -pot, large -scale synthesis of magnetic activated carbon nanotubes and their applications for arsenic removal," Journal of Materials Chemistry A, vol. 1, no. 15, pp. 4662-4666, 2013.

[74] B. K. Mandal and K. T. Suzuki, "Arsenic round the world: a review," Talanta, vol. 58, no. 1, pp. 201-235, 2002.

[75] B. An, Q. Liang, and D. Zhao, "Removal of arsenic(V) from spent ion exchange brine using a new class of starch-bridged magnetite nanoparticles," Water Research, vol. 45, no. 5, pp. 1961-1972, 2011.

[76] Arsenic in drinking water, http://water.epa.gov/lawsregs/rulesregs/sdwa/arsenic/index.cfm.

[77] W. Yang, A. T. Kan, W. Chen, and M. B. Tomson, "PHdependent effect of zinc on arsenic adsorption to magnetite nanoparticles," Water Research, vol. 44, no. 19, pp. 5693-5701, 2010.

[78] C. T. Yavuz, J. T. Mayo, C. Suchecki et al., "Pollution magnet: nano-magnetite for arsenic removal from drinking water," Environmental Geochemistry and Health, vol. 32, no. 4, pp. 327334, 2010.

[79] Y. Jeong, M. Fan, S. Singh, C.-L. Chuang, B. Saha, and J. Hans van Leeuwen, "Evaluation of iron oxide and aluminum oxide as potential arsenic(V) adsorbents," Chemical Engineering and Processing, vol. 46, no. 10, pp. 1030-1039, 2007.

[80] L. Feng, M. Cao, X. Ma, Y. Zhu, and C. Hu, "Superparamagnetic high-surface-area $\mathrm{Fe}_{3} \mathrm{O}_{4}$ nanoparticles as adsorbents for arsenic removal," Journal of Hazardous Materials, vol. 217-218, pp. 439446, 2012.

[81] X. Yu, S. Tong, M. Ge, J. Zuo, C. Cao, and W. Song, “One-step synthesis of magnetic composites of cellulose@iron oxide nanaparticles for arsenic removal," Journal of Materials Chemistry A, vol. 1, no. 3, pp. 959-965, 2013.

[82] R. Chalasani and S. Vasudevan, "Cyclodextrin functionalized magnetic iron oxide nanocrystal: a host -carrier for magnetic separation of non -polar molecules and arsenic from aqueous media," Journal of Materials Chemistry, vol. 22, pp. 14925-14931, 2012.

[83] F. Mou, J. Guan, Z. Xiao, Z. Sun, W. Shi, and X.-A. Fan, "Solvent-mediated synthesis of magnetic $\mathrm{Fe}_{2} \mathrm{O}_{3}$ chestnutlike amorphous-core $/ \gamma$-phase-shell hierarchical nanostructures with strong As(v) removal capability," Journal of Materials Chemistry, vol. 21, no. 14, pp. 5414-5421, 2011.

[84] Y.-M. Hao, C. Man, and Z.-B. Hu, "Effective removal of Cu (II) ions from aqueous solution by amino-functionalized magnetic nanoparticles," Journal of Hazardous Materials, vol. 184, no. 1-3, pp. 392-399, 2010.

[85] H. Li, D.-L. Xiao, H. He, R. Lin, and P.-L. Zuo, "Adsorption behavior and adsorption mechanism of $\mathrm{Cu}$ (II) ions on aminofunctionalized magnetic nanoparticles," Transactions of Nonferrous Metals Society of China, vol. 23, no. 9, pp. 2657-2665, 2013.

[86] S. S. Banerjee and D.-H. Chen, "Fast removal of copper ions by gum arabic modified magnetic nano-adsorbent," Journal of Hazardous Materials, vol. 147, no. 3, pp. 792-799, 2007.

[87] Y.-T. Zhou, H.-L. Nie, C. Branford-White, Z.-Y. He, and L.-M. $\mathrm{Zhu}$, "Removal of $\mathrm{Cu}^{2+}$ from aqueous solution by chitosancoated magnetic nanoparticles modified with $\alpha$-ketoglutaric 
acid," Journal of Colloid and Interface Science, vol. 330, no. 1, pp. 29-37, 2009.

[88] Y.-C. Chang and D.-H. Chen, "Preparation and adsorption properties of monodisperse chitosan-bound $\mathrm{Fe}_{3} \mathrm{O}_{4}$ magnetic nanoparticles for removal of $\mathrm{Cu}(\mathrm{II})$ ions," Journal of Colloid and Interface Science, vol. 283, no. 2, pp. 446-451, 2005.

[89] H. Yan, L. Yang, Z. Yang, H. Yang, A. Li, and R. Cheng, "Preparation of chitosan/poly (acrylic acid) magnetic composite microspheres and applications in the removal of copper (II) ions from aqueous solutions," Journal of Hazardous Materials, vol. 229-230, pp. 371-380, 2012.

[90] J.-Y. Tseng, C.-Y. Chang, C.-F. Chang et al., "Kinetics and equilibrium of desorption removal of copper from magnetic polymer adsorbent," Journal of Hazardous Materials, vol. 171, no. 1-3, pp. 370-377, 2009.

[91] A. Z. M. Badruddoza, A. S. H. Tay, P. Y. Tan, K. Hidajat, and M. S. Uddin, "Carboxymethyl- $\beta$-cyclodextrin conjugated magnetic nanoparticles as nano-adsorbents for removal of copper ions: synthesis and adsorption studies," Journal of Hazardous Materials, vol. 185, no. 2-3, pp. 1177-1186, 2011.

[92] J. Zhu, S. Wei, H. Gu et al., "One-pot synthesis of magnetic graphene nanocomposites decorated with core@double-shell nanoparticles for fast chromium removal," Environmental Science and Technology, vol. 46, no. 2, pp. 977-985, 2012.

[93] P. Yuan, M. Fan, D. Yang et al., "Montmorillonite-supported magnetite nanoparticles for the removal of hexavalent chromium $[\mathrm{Cr}(\mathrm{VI})]$ from aqueous solutions," Journal of Hazardous Materials, vol. 166, no. 2-3, pp. 821-829, 2009.

[94] G. López-Téllez, C. E. Barrera-Díaz, P. Balderas-Hernández, G. Roa-Morales, and B. Bilyeu, "Removal of hexavalent chromium in aquatic solutions by iron nanoparticles embedded in orange peel pith," Chemical Engineering Journal, vol. 173, no. 2, pp. 480485, 2011.

[95] Y. Wang, B. Zou, T. Gao, X. Wu, S. Lou, and S. Zhou, "Synthesis of orange-like $\mathrm{Fe}_{3} \mathrm{O}_{4} / \mathrm{PPy}$ composite microspheres and their excellent $\mathrm{Cr}(\mathrm{VI})$ ion removal properties," Journal of Materials Chemistry, vol. 22, no. 18, pp. 9034-9040, 2012.

[96] N. N. Nassar, "Rapid removal and recovery of $\mathrm{Pb}$ (II) from wastewater by magnetic nanoadsorbents," Journal of Hazardous Materials, vol. 184, no. 1-3, pp. 538-546, 2010.

[97] Z. Cheng, A. L. KuanTan, Y. Tao, D. Shan, K. E. Ting, and X. J. Yin, "Synthesis and characterization of iron Oxide nanoparticles and applications in the removal of heavy Metals from industrial wastewater," International Journal of Photoenergy, vol. 2012, pp. 1-5, 2012.

[98] P. Xu, G. M. Zeng, D. L. Huang et al., "Adsorption of $\mathrm{Pb}$ (II) by iron oxide nanoparticles immobilized phanerochaete chrysosporium: equilibrium, kinetic, thermodynamic and mechanisms analysis," Chemical Engineering Journal, vol. 203, pp. 423-431, 2012.

[99] T. Madrakian, A. Afkhami, and M. Ahmadi, "Simple in situ functionalizing magnetite nanoparticles by reactive blue-19 and their application to the effective removal of $\mathrm{Pb}^{2+}$ ions from water samples," Chemosphere, vol. 90, no. 2, pp. 542-547, 2013.

[100] L. Wang, J. Li, Q. Jiang, and L. Zhao, "Water-soluble $\mathrm{Fe}_{3} \mathrm{O}_{4}$ nanoparticles with high solubility for removal of heavy-metal ions from waste water," Dalton Transactions, vol. 41, no. 15, pp. 4544-4551, 2012.

[101] C.-Y. Cao, J. Qu, W.-S. Yan, J.-F. Zhu, Z.-Y. Wu, and W.-G. Song, "Low-cost synthesis of flowerlike $\alpha-\mathrm{Fe}_{2} \mathrm{O}_{3}$ nanostructures for heavy metal ion removal: adsorption property and mechanism," Langmuir, vol. 28, no. 9, pp. 4573-4579, 2012.
[102] Z. Wei, R. Xing, X. Zhang, S. Liu, H. Yu, and P. Li, "Facile template-free fabrication of hollow nestlike $\alpha-\mathrm{Fe}_{2} \mathrm{O}_{3}$ nanostructures for water treatment," ACS Applied Materials \& Interfaces, vol. 5, no. 3, pp. 598-604, 2013.

[103] A. Roy and J. Bhattacharya, "Removal of $\mathrm{Cu}$ (II), Zn (II) and $\mathrm{Pb}$ (II) from water using microwave-assisted synthesized maghemite nanotubes," Chemical Engineering Journal, vol. 211212, pp. 493-500, 2012.

[104] C. Zhang, J. Sui, J. Li, Y. Tang, and W. Cai, "Efficient removal of heavy metal ions by thiol-functionalized super magnetic carbon nanotubes," Chemical Engineering Journal, vol. 210, pp. 45-52, 2012.

[105] H. Parham, B. Zargar, and R. Shiralipour, "Fast and efficient removal of mercury from water samples using magnetic iron oxide nanoparticles modified with 2-mercaptobenzothiazole," Journal of Hazardous Materials, vol. 205-206, pp. 94-100, 2012.

[106] X. Xin, Q. Wei, J. Yang et al., "Highly efficient removal of heavy metal ions by amine-functionalized mesoporous $\mathrm{Fe}_{3} \mathrm{O}_{4}$ nanoparticles," Chemical Engineering Journal, vol. 184, pp. 132140, 2012.

[107] F. Ge, M.-M. Li, H. Ye, and B.-X. Zhao, "Effective removal of heavy metal ions $\mathrm{Cd}^{2+}, \mathrm{Zn}^{2+}, \mathrm{Pb}^{2+}, \mathrm{Cu}^{2+}$ from aqueous solution by polymer-modified magnetic nanoparticles," Journal of Hazardous Materials, vol. 211-212, pp. 366-372, 2012.

[108] J.-F. Liu, Z.-S. Zhao, and G.-B. Jiang, "Coating $\mathrm{Fe}_{3} \mathrm{O}_{4}$ magnetic nanoparticles with humic acid for high efficient removal of heavy metals in water," Environmental Science and Technology, vol. 42, no. 18, pp. 6949-6954, 2008.

[109] S. Singh, K. C. Barick, and D. Bahadur, "Surface engineered magnetic nanoparticles for removal of toxic metal ions and bacterial pathogens," Journal of Hazardous Materials, vol. 192, no. 3, pp. 1539-1547, 2011.

[110] A. Z. M. Badruddoza, Z. B. Shawon, W. J. Tay, K. Hidajat, and M. S. Uddin, " $\mathrm{Fe}_{3} \mathrm{O}_{4}$ /cyclodextrin polymer nanocomposites for selective heavy metals from industrial wastewater," Carbohydrate Polymers, vol. 91, no. 1, pp. 322-332, 2013.

[111] J. Gong, L. Chen, G. Zeng et al., "Shellac-coated ironoxide nanaparticles for removal of cadmium (II) ions from aqueous solution," Journal of Environmental Sciences, vol. 24, no. 7, pp. 1165-1173, 2012.

[112] W. Yantasee, C. L. Warner, T. Sangvanich et al., "Removal of heavy metals from aqueous systems with thiol functionalized superparamagnetic nanoparticles," Environmental Science and Technology, vol. 41, no. 14, pp. 5114-5119, 2007.

[113] Y. Tan, M. Chen, and Y. Hao, "High efficient removal of $\mathrm{Pb}$ (II) by amino-functionalized $\mathrm{Fe}_{3} \mathrm{O}_{4}$ magnetic nano-particles," Chemical Engineering Journal, vol. 191, pp. 104-111, 2012.

[114] Y. F. Shen, J. Tang, Z. H. Nie, Y. D. Wang, Y. Ren, and L. Zuo, "Preparation and application of magnetic $\mathrm{Fe}_{3} \mathrm{O}_{4}$ nanoparticles for wastewater purification," Separation and Purification Technology, vol. 68, no. 3, pp. 312-319, 2009.

[115] F. Zhang, Z. Zhu, Z. Dong et al., "Magnetically recoverable facile nanomaterials: synthesis, characterization and application in remediation of heavy metals," Microchemical Journal, vol. 98, no. 2, pp. 328-333, 2011.

[116] A. Farrukh, A. Akram, A. Ghaffar et al., "Design of polymerbrush grafted magnetic nanaparticles for highly efficient water remediation," Mater Interfaces, vol. 5, no. 9, pp. 3784-3793, 2013.

[117] S. Yang, Z. Guo, G. Sheng, and X. Wang, "Application of novel plasma-induced CD/MWCNT/ iron oxide composite in zinc decontamination," Carbohydrate Polymers, vol. 90, no. 2, pp. 1100-1105, 2012. 
[118] E.-J. Kim, C.-S. Lee, Y.-Y. Chang, and Y.-S. Chang, "Hierarchically structured manganese oxide -caoted magnetic nanocomposites for the efficient removal of heavy metal ions from aqueous systems," ACS Applied Materials \& Interfaces, vol. 19, no. 5, pp. 9628-9634, 2013.

[119] S. Singh, K. C. Barick, and D. Bahadur, " $\mathrm{Fe}_{3} \mathrm{O}_{4}$ embedded Zno nanocomposites for the removal of toxic metal ions organic dyes and bacterial pathogens," Journal of Materials Chemistry A, vol. 1, no. 10, pp. 3325-3333, 2013.

[120] Z. Ma, D. Zhao, Y. Chang, S. Xing, Y. Wu, and Y. Gao, "Synthesis of $\mathrm{MnFe}_{2} \mathrm{O}_{4} @ \mathrm{Mn}$-Co oxide core-shell nanaparticles and their excellent performance for heavy metal removal," Dalton Transactions, vol. 42, no. 39, pp. 14261-14267, 2013.

[121] S.-H. Huang and D.-H. Chen, "Rapid removal of heavy metal cations and anions from aqueous solutions by an aminofunctionalized magnetic nano-adsorbent," Journal of Hazardous Materials, vol. 163, no. 1, pp. 174-179, 2009.

[122] A. R. Mahdavian and M. A.-S. Mirrahimi, "Efficient separation of heavy metal cations by anchoring polyacrylic acid on superparamagnetic magnetite nanoparticles through surface modification," Chemical Engineering Journal, vol. 159, no. 1-3, pp. 264-271, 2010.

[123] H. Karami, "Heavy metal removal from water by magnetite nanorods," Chemical Engineering Journal, vol. 219, pp. 209-216, 2013.

[124] A. E. Karatapanis, Y. Fiamegos, and C. D. Stalikas, "Silicamodified magnetic nanoparticles functionalized with cetylpyridinium bromide for the preconcentration of metals after complexation with 8-hydroxyquinoline," Talanta, vol. 84, no. 3, pp. 834-839, 2011.

[125] C. Caparrós, M. Benelmekki, P. M. Martins et al., "Hydrothermal assisted synthesis of iron oxide-based magnetic silica spheres and their performance in magnetophoretic water purification," Chemical Physics, vol. 135, pp. 510-517, 2012.

[126] J. Wang, S. Zheng, Y. Shao, J. Liu, Z. Xu, and D. Zhu, "Aminofunctionalized $\mathrm{Fe}_{3} \mathrm{O}_{4} @ \mathrm{SiO}_{2}$ core-shell magnetic nanomaterial as a novel adsorbent for aqueous heavy metals removal," Journal of Colloid and Interface Science, vol. 349, no. 1, pp. 293-299, 2010.

[127] S. Zhang, Y. Zhang, J. Liu et al., “Thiol modified $\mathrm{Fe}_{3} \mathrm{O}_{4} @ \mathrm{SiO}_{2}$ as a robust, high effective and recycling magnetic sorbent for mercury removal," Chemical Engineering Journal, vol. 226, pp. 30-38, 2013.

[128] Q. Yuan, N. Li, Y. Chi et al., "Effect of large pore size of multifunctional mesoporous microsphere on removal of heavy metal ions," Journal of Hazardous Materials, vol. 254-255, pp. 157-165, 2013.

[129] G. Li, Z. Zhao, J. Liu, and G. Jiang, "Effective heavy metal removal from aqueous systems by thiol functionalized magnetic mesoporous silica," Journal of Hazardous Materials, vol. 192, no. 1, pp. 277-283, 2011.

[130] M. Baikousi, A. B. Bourlinos, A. Douvalis et al., "Synthesis and characterization of $\gamma-\mathrm{Fe}_{2} \mathrm{O}_{3}$ /carbon hybrids and their application in removal of hexavalent chromium ions from aqueous solutions," Langmuir, vol. 28, no. 8, pp. 3918-3930, 2012. 

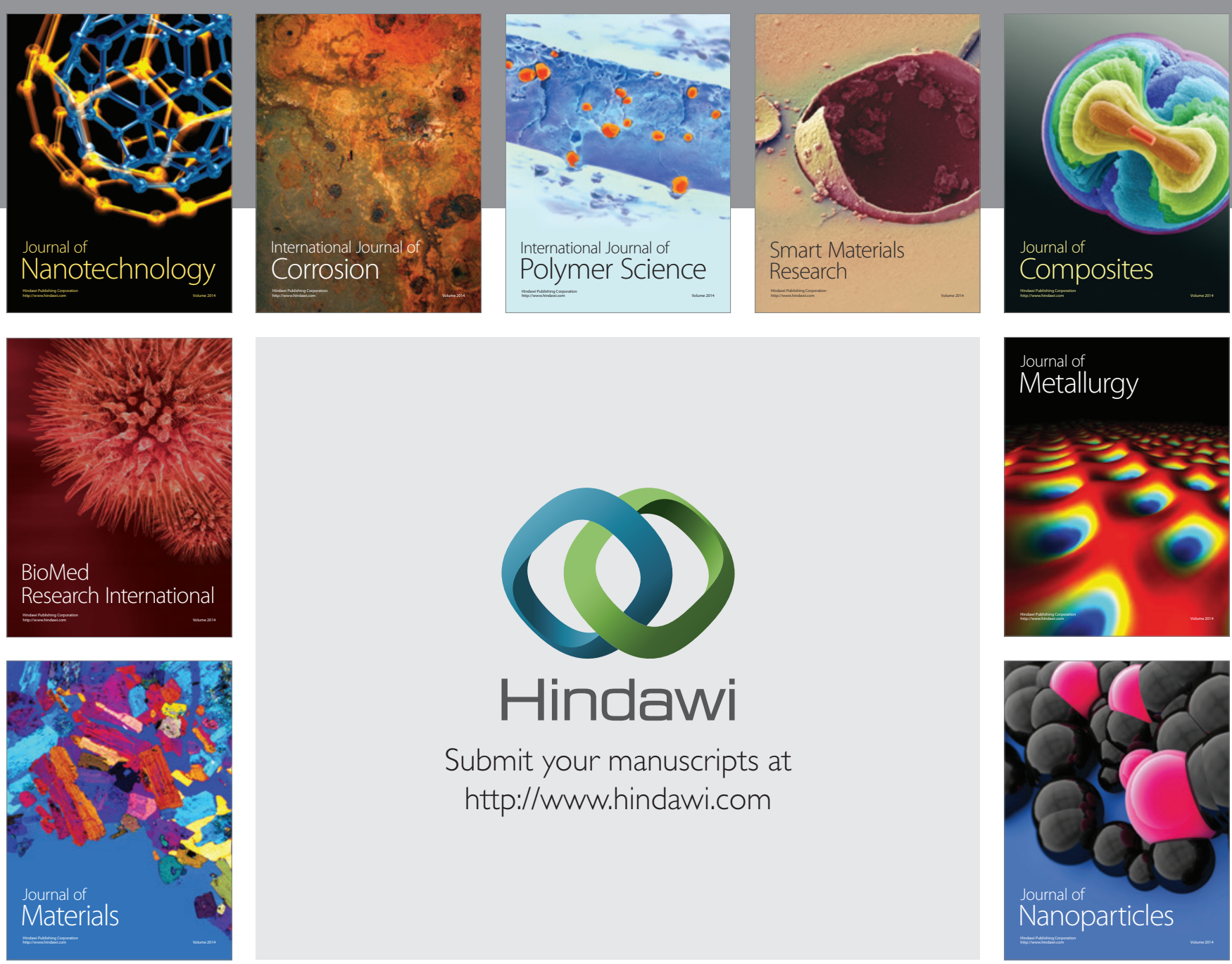

Submit your manuscripts at http://www.hindawi.com
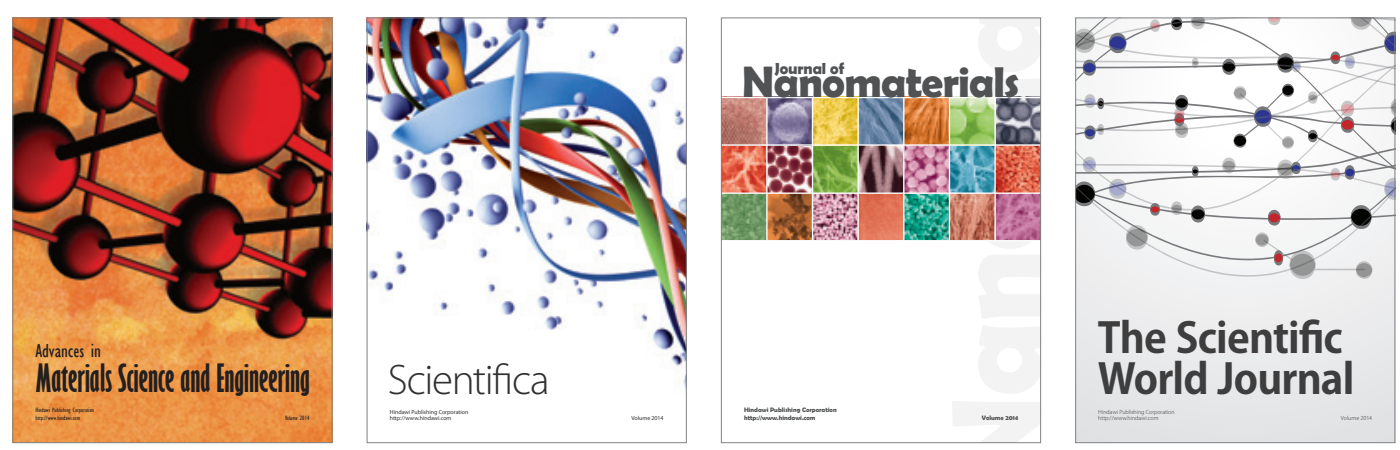

\section{The Scientific World Journal}
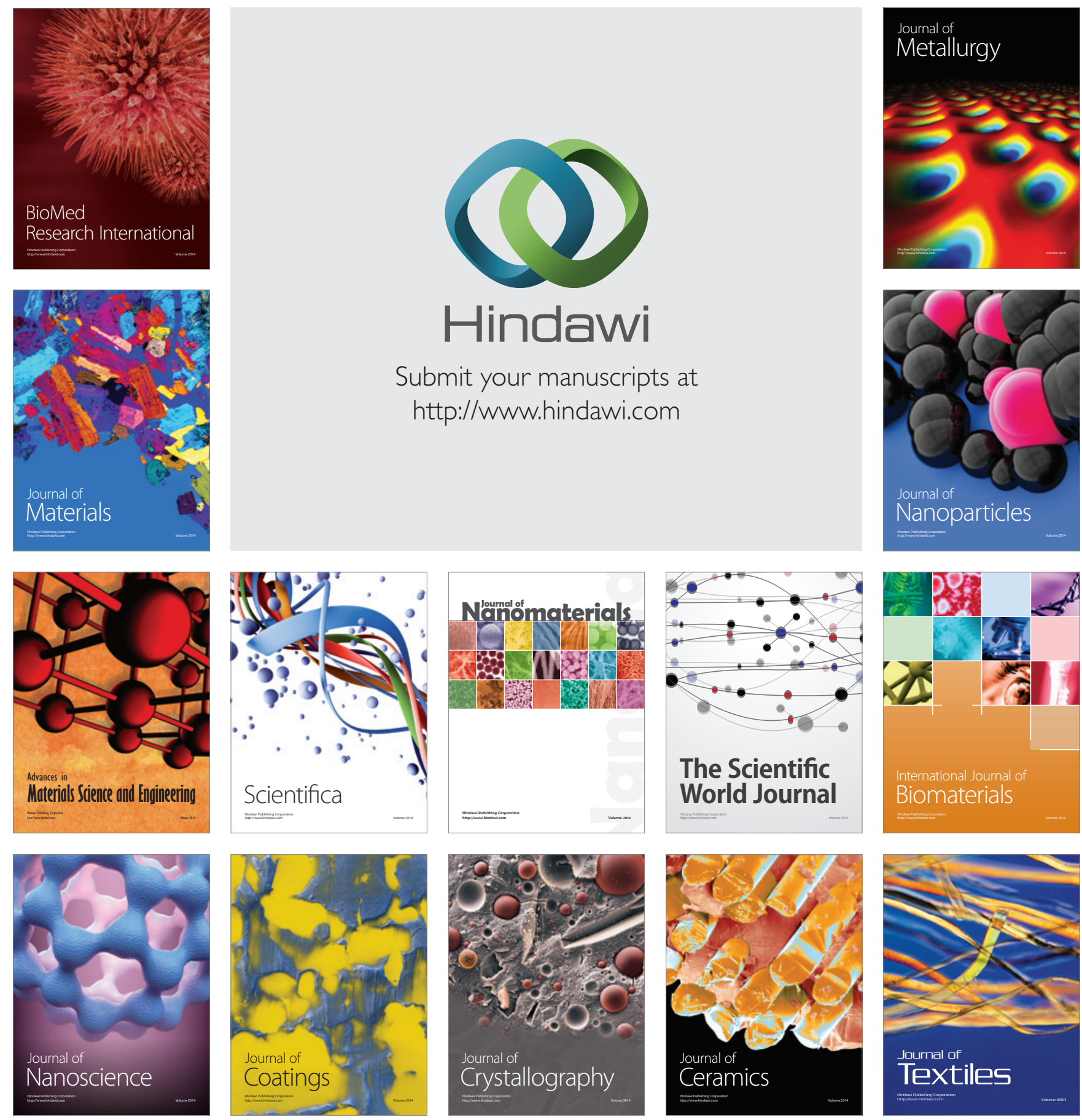